\title{
Seminal vesicle fluid increases the efficacy of intravaginal HSV-2 vaccination
}

\author{
A Varese ${ }^{1}$, F Remes Lenicov ${ }^{1}$, M Gonzalez Prinz $^{1}$, A Paletta ${ }^{1}$, G Ernst $^{1}$, C Maeto $^{1}$, A Merlotti $^{1}$, J Sabatte ${ }^{1}$, \\ S Símula ${ }^{2}$, MP Holgado ${ }^{1}$, E Dantas $^{1}$, J Geffner ${ }^{1}$ and A Ceballos ${ }^{1}$
}

Once considered merely as a vehicle for spermatozoa, it is now clear that seminal plasma (SP) induces a variety of biological actions on the female reproductive tissues able to modulate the immune response against paternal antigens. To our knowledge, the influence of SP on the immune response against sexually transmitted pathogens has not been yet evaluated. We here analyzed whether the seminal vesicle fluid (SVF), which contributes almost $60 \%$ of the SP volume in mice, could modulate the immune response against herpes simplex virus type 2 (HSV-2). We found that SVF does not modify the course of primary infection, but markedly improved protection conferred by vaginal vaccination with inactivated HSV-2 against a lethal challenge. This protective effect was shown to be associated to a robust memory immune response mediated by CD4 + and CD8 + T cells in both the lymph nodes draining the vagina and the vaginal mucosa, the site of viral replication. In contrast with the widespread notion that SP acts as an immunosuppressive agent, our results suggest that SVF might improve the female immune response against sexually transmitted pathogens.

\section{INTRODUCTION}

Seminal plasma (SP) is a complex fluid. Although it has long been considered merely as a carrier for spermatozoa and the main vector for sexually transmitted infectious diseases, it is now known that SP exerts two major immunomodulatory effects on the female reproductive tract: an acute inflammatory reaction mediated by innate immune cells and a tolerogenic immune response against paternal antigens via the induction of $\mathrm{CD} 4+\mathrm{CD} 25+\mathrm{FOXP} 3+$ regulatory T cells $\left(\right.$ Tregs). ${ }^{1-4}$

The properties of SP are quite different from other body fluids. It contains a large variety of components including carbohydrates, lipids, and proteins produced by the testis, the epididymis, and the accessory glands. ${ }^{5}$ Protein concentration in the $\mathrm{SP}$ is 35 to $55 \mathrm{gl}^{-1}$ and more than 900 proteins have been identified by proteomic analysis. ${ }^{6}$ Some of the unique properties of SP are associated with the presence of high concentrations of immunomodulatory agents. The concentration of transforming growth factor (TGF)- $\beta$ is unusually high (range $60-240 \mathrm{n} \mathrm{ml}^{-1}$ ), about fivefold higher than the concentration found in the serum. ${ }^{7}$ Interestingly, unlike serum TGF- $\beta$, which is present in the latent form, $25 \%$ of semen TGF- $\beta$ exists in the active form. ${ }^{8}$ Prostaglandins of the E series, including PGE1, PGE2, and their 19-OH derivatives are found in SP at concentrations exceeding $700 \mu \mathrm{g} \mathrm{ml}^{-1}$ (ref. 9). This concentration is about 100,000-fold higher than that found in the serum. Moreover, high levels $\left(50-1,000 \mathrm{pg} \mathrm{ml}^{-1}\right)$ of other cytokines, including stromal cell-derived factor-1a, monocyte chemoattractant protein-1, RANTES (regulated on activation, normal $\mathrm{T}$ cell expressed and secreted), macrophage inflammatory protein- $1 \beta$, interferon (IFN) $-\alpha$, granulocyte colonystimulating factor, interleukin (IL)-1 $\beta$, IL-5, IL-6, IL-8, IL-13, and IL-17A have been found in normal human SP. ${ }^{6,7}$ This unique cytokine signature might enable SP to modulate the immune response in the female reproductive tract.

Deposition of semen in the receptive mucosa triggers two major and contrasting effects: inflammation and immune tolerance. ${ }^{1-4}$ The link between both responses, if any, remains unknown. Acting on epithelial cells, SP stimulates the production of monocyte chemoattractant protein-1, granulocyte-colony-stimulating factor, IL-6, IL-8, the expression of cyclooxygenase-2, and the secretion of CCL20, resulting in the recruitment of professional antigen-presenting cells. ${ }^{10}$

${ }^{1}$ Instituto de Investigaciones Biomédicas en Retrovirus y SIDA (INBIRS), Universidad de Buenos Aires (UBA) and Consejo Nacional de Investigaciones Científicas y Técnicas (CONICET), Buenos Aires, Argentina and ${ }^{2}$ Instituto de Microbiología y Parasitología Médica (IMPaM), UBA-CONICET, Buenos Aires, Argentina. Correspondence: A Ceballos (aceballo@fmed.uba.ar) 
Consistent with these findings, serial analysis of human cervical samples performed by Robertson's lab has shown that semen deposition induces the infiltration of the cervix by neutrophils, monocytes, and dendritic cells (DCs). ${ }^{4}$ Of note, this inflammatory response is mainly mediated by TGF- $\beta$, a cytokine traditionally known for its immunosuppressive function. ${ }^{8}$ On the other hand, SP has a well-recognized ability to induce maternal immune tolerance to paternal antigens by stimulating the differentiation and expansion of Tregs, preventing an adverse immune response directed to the spermatozoa or the embryo (a semi-allograft). This tolerogenic effect is induced even in the absence of conception, suggesting a major role for SP in eliciting this response. ${ }^{11}$ The mechanism involved has not been yet clarified; however, we have recently reported that SP promotes the differentiation of DCs into a tolerogenic profile, thus suggesting a possible explanation for the ability of SP to promote the development of Tregs. ${ }^{12}$ Moreover, we also showed that a protein found at high concentrations in the SP, clusterin, promotes the expansion of Tregs by DCs. ${ }^{13}$ A very important question that remains to be answered is whether deposition of SP in the female reproductive tract might also be capable of suppressing the adaptive immune response against pathogens in a similar way to the immune response against paternal antigens. As semen is the main vector for sexually transmitted infectious diseases that annually causes millions of deaths in the world, ${ }^{14}$ it is striking that the ability of semen to modulate the course of the anti-microbial immune response has not been analyzed. Previous studies directed to analyze the impact of seminal fluid on herpes simplex virus type 2 (HSV-2) infection have focused on its effect on both, HSV-2 infectivity and the effectiveness of anti-HSV-2 microbicides. They showed that SP modified neither in vitro HSV-2 infectivity nor the course of primary infection in mice. ${ }^{15,16}$ Moreover, these studies demonstrated that SP markedly reduces the effectiveness of topical polyanionic microbicides. ${ }^{15}$

In the present study, we used a well-characterized mouse model of genital HSV-2 infection by intravaginal route (IVAG) as a tool to analyze whether seminal vesicle fluid (SVF), which represents the major constituent of SP in rodents, might act to modulate the immune response against HSV-2. We found that SVF markedly improved the protective effect induced by IVAG vaccination with inactivated $\mathrm{HSV}-2$, by boosting a $\mathrm{T}$ cell memory response.

\section{RESULTS \\ SVF does not modulate the course of primary infection with HSV-2}

In a first set of experiments we analyzed whether SVF could modulate the ability of HSV-2 to infect epithelial cells in vitro. In these experiments, Vero cell monolayers were infected with HSV-2 in the absence or presence of different concentrations of SVF and viral production was evaluated after $48 \mathrm{~h}$ of culture by measuring plaque forming units (pfu). Results in Figure 1a show that SVF did not modify HSV-2 infectivity. Then, we evaluated whether SVF was able to modulate in vivo the course of primary infection with HSV-2. We used a well-characterized
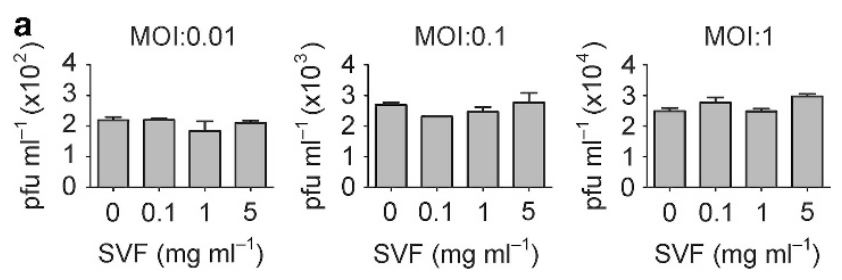

b
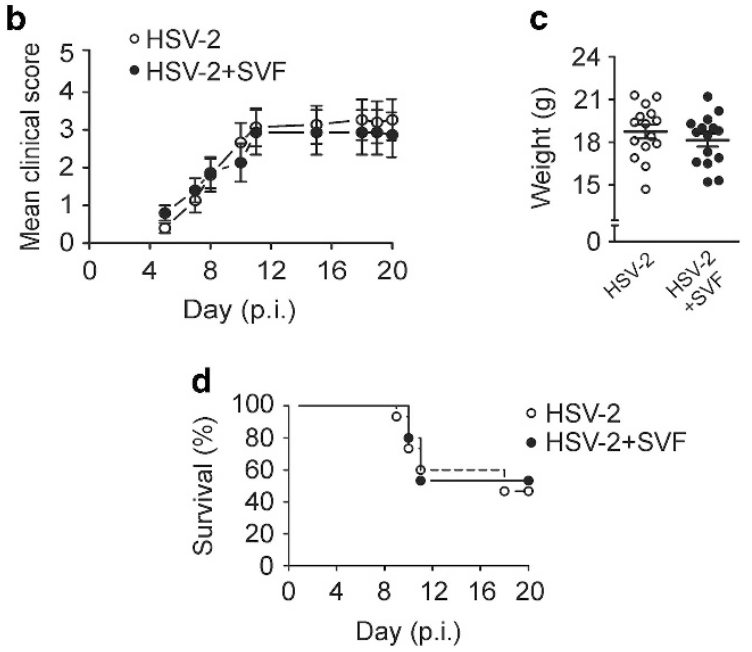

Figure 1 Seminal vesicle fluid (SVF) does not modulate HSV-2 primary infection. (a) Vero cells were infected with HSV-2 (multiplicity of infection (MOI): $0.01 ; 0.1$ and 1 ), in the absence or presence of different concentrations of SVF. Viral replication was quantified after $48 \mathrm{~h}$ of culture by plaque forming unit (pfu) assays performed in triplicate. Results are expressed as the mean \pm s.d. Representative experiments are shown $(n=3)$. (b-d) Groups of 15 medroxyprogesterone (Mp)-pretreated mice were challenged intravaginal route (IVAG) with HSV-2 $\left(1 \times 10^{5}\right.$ pfu per $15 \mu \mathrm{l})$, without (HSV-2) or with SVF (HSV-2 + SVF), at a final SVF protein concentration of $5 \mathrm{mg} \mathrm{ml}^{-1}$. Mice were examined daily for their clinical score ( 0 , no sign; 1 , slight genital erythema and edema; 2 , moderate genital inflammation; 3 , purulent genital lesions; 4 , hind limb paralysis; and 5, pre-moribund) (b), weight (at day 7 post infection) (c), and survival (d). Results are expressed as the mean \pm s.e.m. of the clinical score (b), weight (c), or as the survival (d) of 15 mice per each group. Data from a representative experiment $(n=3)$ is shown.

mouse model of genital HSV-2 infection via a natural route. In this model, viral replication is initially limited to the vaginal mucosa, followed by dissemination via retrograde transport to the central nervous system, resulting in paralysis and death. ${ }^{17,18}$ Groups of 15 medroxyprogesterone (Mp)-pretreated mice were IVAG challenged with HSV-2 $\left(1 \times 10^{5}\right.$ pfu per $\left.15 \mu \mathrm{l}\right)$, without or with SVF, at a final SVF protein concentration of $5 \mathrm{mg} \mathrm{ml}^{-1}$, similar to that deposited in the vaginal tract after natural coitus. ${ }^{19,20}$ Mice were examined daily for their clinical score (Figure 1b), weight (Figure 1c) and survival (Figure 1d). Because of the known immunosuppressive properties of semen, we hypothesized that SVF might aggravate the course of disease. However, results in Figure 1b-d show that neither disease development nor the survival rates of infected mice were affected by the presence of SVF in the infectious inoculum. Similar results were observed when groups of $10 \mathrm{Mp}$-pretreated mice were IVAG challenged with a higher dose of HSV-2 $\left(2 \times 10^{6}\right.$ pfu per $\left.15 \mu \mathrm{l}\right)$ (Supplementary Figure 1 online). We 
conclude that SVF does not modify the course of primary infection by HSV-2.

\section{SVF improves the efficacy of vaginal vaccination with inactivated HSV-2}

We then analyzed whether SVF might compromise the induction of a protective memory response induced by HSV-2 vaccination. In the course of preliminary experiments, we unexpectedly found that SVF did not compromise, but rather it improved the protective effect induced by IVAG vaccination. Taking these observations into account, we decided to analyze the modulatory effect of SVF using a low inoculum of inactivated HSV-2 $(1 \times 104$ superindex pfu per $15 \mu \mathrm{l}$ ) as a vaccine immunogen, which was unable per se to induce any protection (data not shown). Groups of $10 \mathrm{Mp}$ pretreated mice were vaccinated IVAG with inactivated HSV-2, without $(\operatorname{Im})$ or with SVF $(\operatorname{Im}+\mathrm{SVF})$, at a final SVF protein concentration of $5 \mathrm{mg} \mathrm{ml}^{-1}$. Control groups were inoculated IVAG with phosphate-buffered saline-bovine serum albumin (PBS-BSA) or SVF alone instead of inactivated HSV-2. Thirty days later, all groups were treated again with $\mathrm{Mp}$ and challenged IVAG with HSV-2 $(2 \times 106$ superindex pfu per $15 \mu \mathrm{l})$, as indicated in Figure 2a. Mice were examined daily for their clinical score (Figure 2b), weight (Figure 2c), and survival (Figure 2d). We found that SVF markedly improved protection induced by IVAG vaccination. In fact, $70 \%$ of the mice vaccinated with virus alone developed severe signs of disease and died within 20 days after challenge, whereas only $20 \%$ of mice vaccinated with HSV-2 plus SVF showed a severe disease and died within the same period. As expected, inoculation of mice with PBS-BSA or SVF (control groups) did not result in the induction of a protective response (Figure $\mathbf{2 b}-\mathbf{d}$ ). For this reason and attending to animal care, the following experiments were performed comparing mice vaccinated with inactivated HSV-2 alone and mice vaccinated with HSV-2 plus SVF, without including control mice inoculated only with PBS-BSA or SVF.

\section{SVF improves T-cell memory response in DLNs of vaccinated mice}

To understand the adjuvant effect exerted by SVF on IVAG vaccination against HSV-2, we analyzed memory T-cell responses in the iliac lymph nodes, the lymph nodes draining the genital mucosa (DLN). Groups of $10 \mathrm{Mp}$-pretreated mice were vaccinated IVAG with inactivated HSV-2 $\left(1 \times 10^{4}\right.$ pfu per $15 \mu \mathrm{l})$, without $(\mathrm{Im})$, or with SVF (Im + SVF), at a final SVF protein concentration of $5 \mathrm{mg} \mathrm{ml}^{-1}$. Thirty days later, mice were treated again with $\mathrm{Mp}$, challenged IVAG with HSV-2 $\left(2 \times 10^{6}\right.$ pfu per $\left.15 \mu \mathrm{l}\right)$, and DLN were obtained 3 days after challenge. Unvaccinated/unchallenged $\mathrm{Mp}$-treated mice were used as controls (c). We found that mice vaccinated IVAG with inactivated HSV-2 plus SVF showed the following: (a) an increased cellularity in DLN (Figure 3a); (b) a similar frequency of $\mathrm{CD} 4+$ and $\mathrm{CD} 8+\mathrm{T}$ cells, but a higher absolute number of $\mathrm{CD} 4+$ and CD8 $+\mathrm{T}$ cells in DLN (Figure 3b); and (c) a higher proliferative response and production of IFN- $\gamma$ by both CD $4+$ and CD $8+$ T cells, after

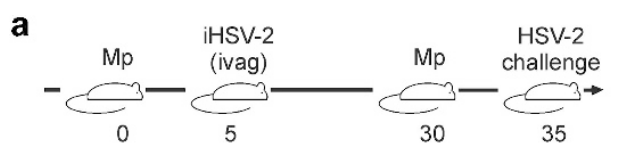

b
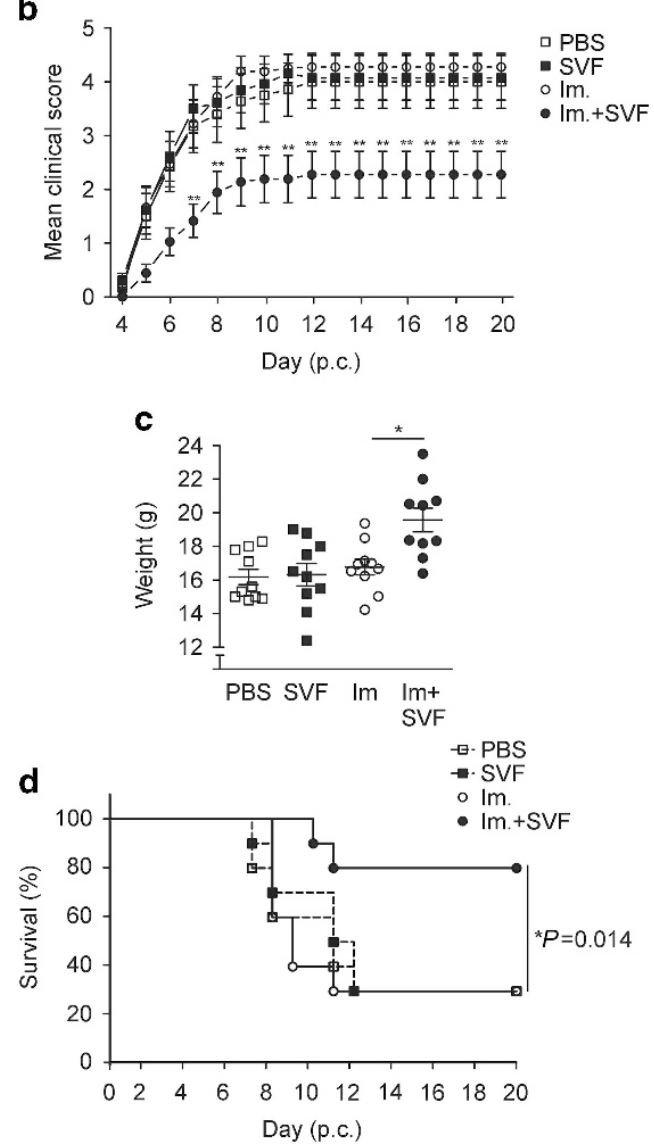

Figure 2 Seminal vesicle fluid (SVF) improves HSV-2 vaccination efficacy. Groups of 10 medroxyprogesterone (Mp)-pretreated mice were inoculated intravaginal route (IVAG) with phosphate-buffered salinebovine serum albumin (PBS-BSA) $\left(5 \mathrm{mg} \mathrm{ml}^{-1}\right)$ (PBS), SVF $\left(5 \mathrm{mg} \mathrm{ml}^{-1}\right)$, and inactivated HSV-2 (iHSV-2) $\left(1 \times 10^{4}\right.$ plaque forming unit $(\mathrm{pfu})$ per $15 \mu \mathrm{l})$ without $(\mathrm{Im})$ or with SVF (Im + SVF), at a final SVF protein concentration of $5 \mathrm{mg} \mathrm{ml}^{-1}$. Thirty days later, mice were treated again with Mp and challenged IVAG with HSV-2 $\left(2 \times 10^{6}\right.$ pfu per $\left.15 \mu \mathrm{l}\right)$, as indicated in (a). Mice were examined daily for their clinical score (b), weight, at day 7 post challenge (p.c.) (c), and survival (d). Results are expressed as the mean \pm s.e.m. of the clinical score (b), weight (c), or as the survival (d) of 10 mice per each group. Data from a representative experiment $(n=3)$ are shown $\left({ }^{*} P<0.05\right.$ and $\left.{ }^{* *} P<0.01\right)$.

in vitro stimulation with inactivated HSV-2 (Figure $3 \mathbf{c}$ and $\mathbf{d}$ ). Considering that UV-inactivated HSV-2 is a crude source of antigens that include PAMPs we also stimulated cells with another UV-inactivated virus (Vaccinia virus) used as a control. Moreover, in order to be sure that SVF actually improved the specific T-cell-mediated memory response against HSV antigens, we stimulated $\mathrm{T}$ cells using a pool of HSV-2 antigenic peptides able to be recognized by $\mathrm{CD} 4+$ or $\mathrm{CD} 8+\mathrm{T}$ cells. Figure $3 \mathbf{e}$ shows a higher number of CD $4+$ and CD8 + IFN- $\gamma$-producing $\mathrm{T}$ cells in mice vaccinated IVAG with inactivated HSV-2 plus SVF after in vitro stimulation with HSV-2 antigenic peptides or UV-inactivated HSV-2. On the 
other hand, and contrasting with the enhanced production of IFN- $\gamma$, we found that the production of IL-10 or TGF- $\beta$, as well as the frequency of Treg, evaluated after in vitro stimulation of $\mathrm{T}$ cells with inactivated HSV-2, did not differ between T cells isolated from mice vaccinated with HSV-2 with or without SVF (Figure 3f-h). Finally, and because the important role that the chemokines CXCL9 and CXCL10 have in the induction of TH1 immunity $^{21,22}$ and the activation of memory T CD8 + cells in lymph nodes, ${ }^{23}$ we analyzed the production of these chemokines by quantitative PCR. Figure $3 \mathbf{i}$ shows that vaccination in the presence of SVF markedly increased the expression of CXCL9 mRNA without modifying CXCL10 mRNA levels.

All the experiments described in Figure 3 were performed in mice first vaccinated with inactivated HSV-2 with or without SVF, and then challenged with HSV-2 30 days later. To further analyze the influence exerted by SVF on the T-cell memory response induced by vaccination, we also analyzed memory $\mathrm{T}$ cells at 28 days after vaccination in unchallenged mice (Figure 4a). Groups of $10 \mathrm{Mp}$-pretreated mice were vaccinated IVAG with inactivated HSV-2 $\left(1 \times 10^{4}\right.$ pfu per $15 \mu \mathrm{l}$ ), without or with SVF, at a final SVF protein concentration of $5 \mathrm{mg} \mathrm{ml}^{-1}$. Twenty eight days later, DLNs were obtained and cells were immediately analyzed by flow cytometry. We found that mice vaccinated IVAG with inactivated HSV-2 plus SVF showed a higher frequency and absolute number of memory/effector-like $\mathrm{T}$ cells $\left(\mathrm{CD} 44^{\text {high }} \mathrm{CD} 2 \mathrm{~L}^{\text {low }}\right)$ and central memory $\mathrm{T}$ cells $\left(\mathrm{CD} 44^{\text {high }}{ }^{\mathrm{CD}} 62 \mathrm{~L}^{\text {high }}\right)$ in both $\mathrm{CD} 4+$ and $\mathrm{CD} 8+\mathrm{T}$-cell compartments, ${ }^{24}$ compared with mice vaccinated without SVF (Figure $\mathbf{4 b}$ and $\mathbf{c}$ ). These changes were shown to be associated with an increased production of IFN $-\gamma$ by CD $4+$ and CD $8+T$ cells from mice vaccinated with SVF (assessed by flow cytometry), after stimulation with HSV-2 antigenic peptides and inactivated HSV-2, but not with inactivated vaccinia virus (Figure $4 \mathbf{d}$ and e). Consistent with this observation, we found higher levels of IFN- $\gamma$, as well as tumor necrosis factor (TNF)- $\alpha$ (assessed by enzyme-linked immunosorbent assay), in the supernatants of T cells from mice vaccinated in the presence of SVF, after stimulation with inactivated HSV-2 (Figure $4 \mathbf{f}$ and $\mathbf{g}$ ). We conclude that the presence of SVF at the time of IVAG vaccination orchestrates a robust memory immune response mediated by $\mathrm{T}$ cells at the lymph nodes draining the vagina.

\section{SVF boosts the T-cell memory response at the infection site in vaccinated mice}

We next analyzed the immune response at the site of viral replication, the vaginal mucosa. Mice were vaccinated and challenged as described above, and the local immune response was studied. Figure 5a shows that the levels of IgA and IgG antibodies directed to HSV-2 in vaginal washes did not differ between mice vaccinated with or without SVF. Similar findings were observed when serum IgG antibodies were studied (Figure 5b). The analysis of the frequency of CD4 + and $\mathrm{CD} 8+\mathrm{T}$ cells in the vaginal mucosa revealed an increased infiltration of CD8 $+\mathrm{T}$ cells in mice vaccinated in the presence of SVF (Figure 5c). Moreover, both CD4 + and CD8 + T cells from vaginal mucosa showed an increased production of IFN- $\gamma$ after in vitro stimulation with inactivated HSV-2 (Figure 5d). In fact, no production of IFN- $\gamma$ was observed in vaginal cell suspensions outside the gate of CD3 + cells (data not shown), indicating that $\mathrm{T}$ cells are the most important source of IFN- $\gamma$. No differences were observed when the presence of Tregs (Figure 5e) or the production of TGF- $\beta$ (Figure 5f) were evaluated. The local increase in CD8 + T-cell infiltration in mice vaccinated with HSV-2 plus SVF was shown to be associated with increased levels of IFN- $\gamma$ and IL-6 in vaginal washes (Figure $5 \mathbf{g}$ ), an increased production of IFN- $\gamma$, TNF- $\alpha$, IL-6, and IL-17A by vaginal cells stimulated in vitro with inactivated HSV-2, and a decreased production of IL-10 (Figure 5h). We conclude that the presence of SVF at the time of IVAG vaccination stimulates the infiltration of vaginal mucosa by $\mathrm{CD} 8+\mathrm{T}$ cells and the production of cytokines classically associated with the induction of a TH1 (IFN- $\gamma$ and TNF- $\alpha$ ) and TH17 profiles (IL-17A), as well as the activation of macrophages into a pro-inflammatory profile (high IL-6 and low IL-10).

\section{$T$ cells mediate the increased protection conferred by vaccination in the presence of SVF}

To demonstrate that $\mathrm{T}$ cells are responsible for the increased protection observed in mice vaccinated in the presence of SVF, we performed adoptive transfer experiments using splenicderived $\mathrm{T}$ cells isolated from mice vaccinated with inactivated HSV-2 in the absence or presence of SVF, at 30 days postvaccination. $\mathrm{CD} 4+$ and $\mathrm{CD} 8+\mathrm{T}$ cells isolated from mice inoculated with PBS-BSA or SVF alone, instead of inactivated HSV-2, were also obtained and used as controls. Five million T cells per mouse (CD4:CD8 T-cell ratio of 3:2) were transferred into Mp-pretreated naive mice and then challenged with HSV$2\left(2 \times 10^{6}\right.$ pfu per $\left.15 \mu \mathrm{l}\right) 18 \mathrm{~h}$ later, as indicated in Figure 6a. Mice were examined daily for their clinical score (Figure 6b), weight (Figure 6c), and survival (Figure 6d). We found that $\mathrm{T}$ cells isolated from mice vaccinated IVAG in the presence of SVF provided a much higher protection compared with $\mathrm{T}$ cells from mice vaccinated IVAG with virus alone. In fact, $70 \%$ of mice transferred with $\mathrm{T}$ cells form mice vaccinated with virus alone developed severe signs of disease and died within 20 days after challenge. Similar results were observed using T cells from mice inoculated with PBS-BSA or SVF alone (controls). By contrast, only $10 \%$ of mice transferred with $\mathrm{T}$ cells isolated form mice vaccinated with HSV-2 plus SVF showed a severe disease and died within the same period. We conclude that $\mathrm{T}$ cells are responsible for the enhanced protection observed in mice vaccinated with inactivated HSV-2 in the presence of SVF.

\section{Vaccination in the presence of SVF boosts an early local inflammatory response}

It has been shown that semen deposition in the female reproductive mucosa results in the induction of a local inflammatory response, which includes the recruitment of innate immune cells such as macrophages and DCs. ${ }^{4} \mathrm{We}$ 
hypothesize that this inflammatory response might provide the adequate environment to promote the development of $\mathrm{TH} 1$ immunity and hence we analyzed whether SVF might increase the production of inflammatory cytokines in the context of IVAG vaccination with $\mathrm{HSV}-2$. Groups of five Mp-pretreated mice were vaccinated IVAG using inactivated HSV-2 $(1 \times$ $10^{4} \mathrm{pfu}$ per $15 \mu \mathrm{l}$ ), without or with SVF, at a final SVF protein concentration of $5 \mathrm{mg} \mathrm{ml}^{-1}$, and $48 \mathrm{~h}$ later, vaginal tissues and
DLN were recovered. Figure $7 \mathbf{a}$ shows that vaginal cell suspensions from mice vaccinated with inactivated HSV-2 plus SVF produced higher levels of IFN- $\gamma$, TNF- $\alpha$, and IL-6, compared with cells obtained from mice vaccinated with inactivated HSV-2 alone. These findings were shown to be associated with a higher frequency of natural killer cells (Figure 7b). Consistent with these observations made in vaginal tissues, the analysis of DLN cells revealed an increased a

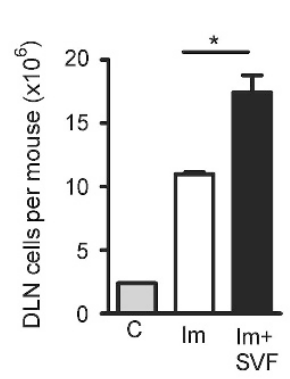

b

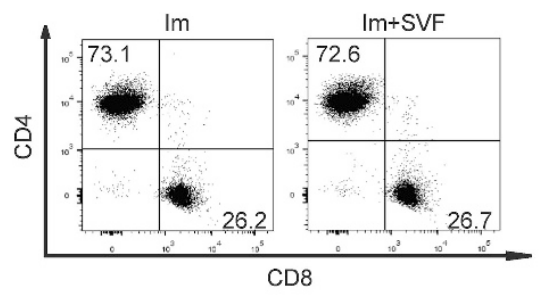

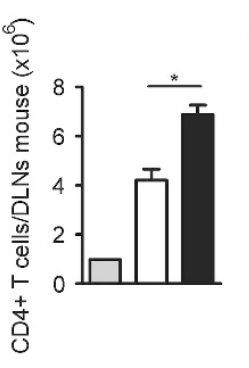

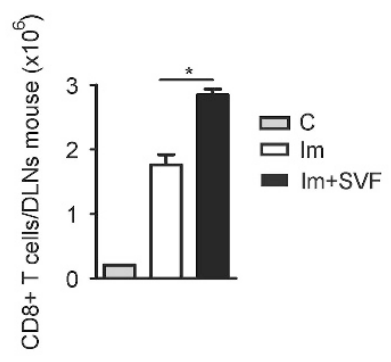

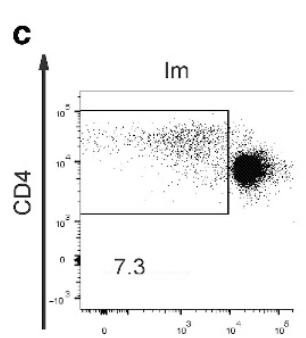

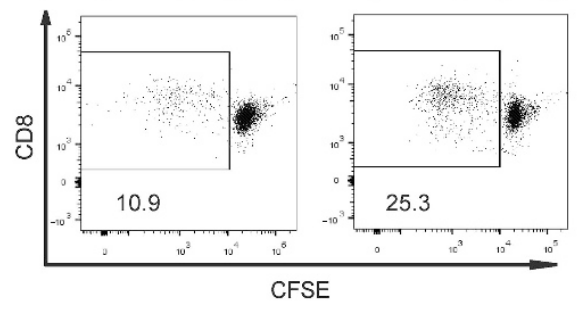

e

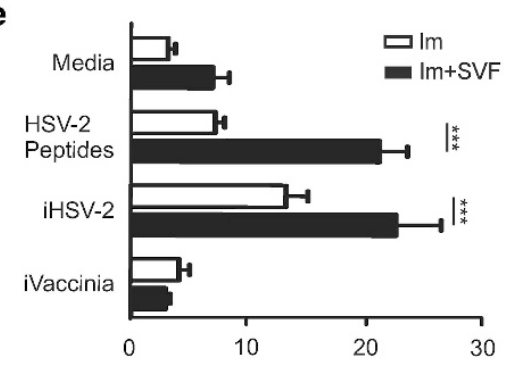

IFN- $\gamma+$ CD4 T cells/DLNs mouse $\left(x 10^{4}\right)$
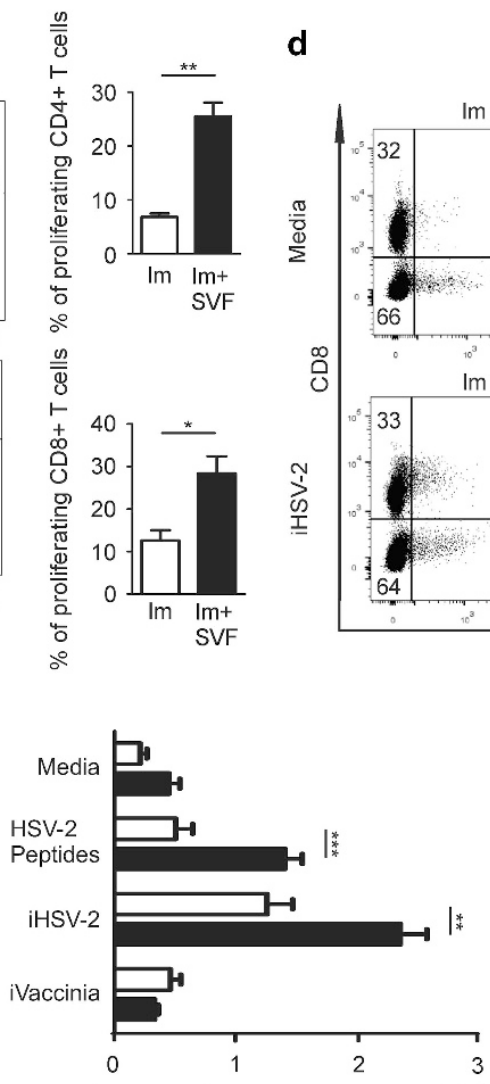

IFN- $\gamma+$ CD 8 T cells/DLNs mouse $\left(\times 10^{4}\right)$
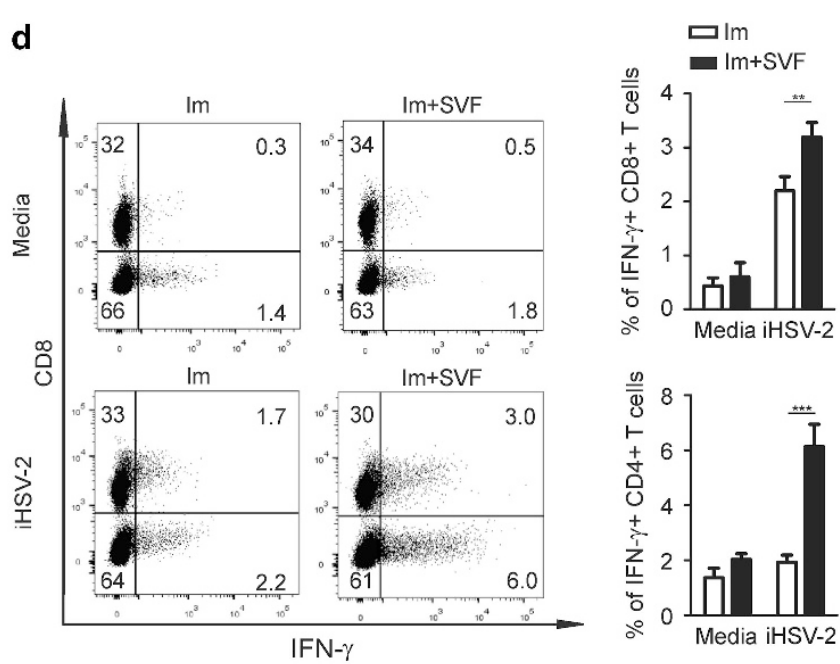

f
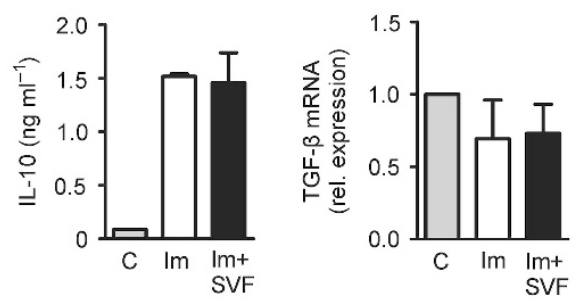

g

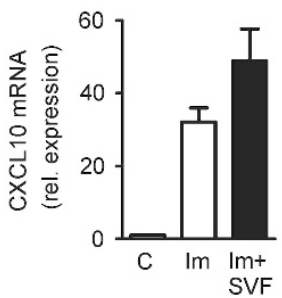

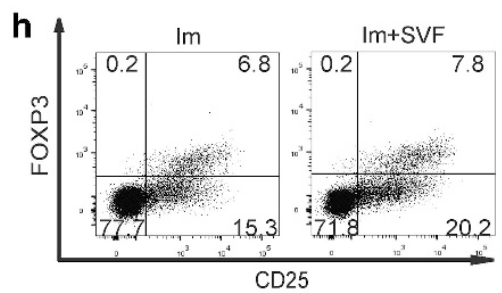

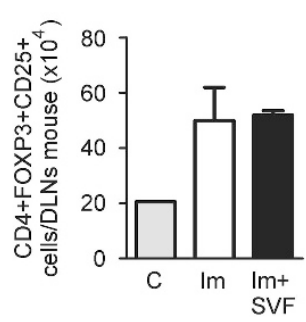

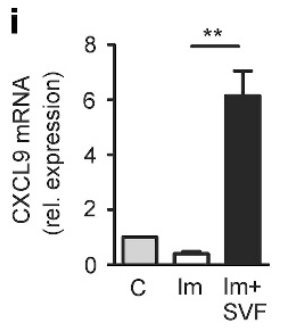


production of IFN- $\gamma$, TNF- $\alpha$, and IL- 6 in mice vaccinated with inactivated HSV-2 plus SVF (Figure 7c). Having shown that SVF promotes the early production of inflammatory cytokines in vaginal tissues and DLN from vaccinated mice, and considering that inflammation is able to induce not only the recruitment but also the phenotypic maturation of DCs, ${ }^{25}$ we next evaluated both the frequency and phenotype of DCs in vagina and DLN. Vaginal cell suspensions from mice inoculated IVAG with SVF, inactivated HSV-2, or SVF plus inactivated HSV-2 showed a frequency of DCs similar than control mice (data not shown). However, inoculation with either SVF or inactivated HSV-2 alone significantly increased the expression of CD86 by DCs. A further increase in the expression of CD86, indicating a more mature phenotype, was observed in DCs from mice inoculated with inactivated HSV-2 plus SVF (Figure 7d). On the other hand, the analysis of DCs in DLN revealed a marked increase in the frequency and the total number of DCs in mice vaccinated with HSV-2 plus SVF (Figure 7e). We conclude that SVF plus inactivated HSV-2 trigger an early inflammatory process favoring the recruitment of DCs in DLN and their phenotypic maturation, thus promoting the induction of a protective immune response mediated by both TH1 and CD $8+\mathrm{T}$ cells.

\section{DISCUSSION}

In this study, we used a well-characterized mouse model of genital HSV-2 infection as a tool to evaluate whether SVF modulate the immune response against HSV-2. We found that SVF markedly improved protection induced by vaginal vaccination against a lethal challenge with HSV-2. Notably, the addition of SVF to a vaccine composed of UV-inactivated HSV-2 increases the survival of mice challenged IVAG with HSV -2 from $30 \%$ to $80 \%$. These results suggest that the adjuvant effect induced by SVF is related to the improvement of the memory response induced by vaccination. Our findings challenge the assumption that SP suppresses the immune response irrespectively of the triggering stimulus, and open the question about the mechanisms through which SP might induce two apparently contrasting effects upon deposition in the female genital tract; a tolerogenic response against paternal antigens via the induction of Tregs, ${ }^{1,3,11}$ and an improved memory $\mathrm{T}$-cell response able to protect the host against sexually transmitted infectious diseases.

By inducing tolerance to paternal alloantigens, Tregs have shown to have a critical role in pregnancy. ${ }^{26}$ Increased numbers of Tregs are found in pregnant mice and humans. ${ }^{27}$ Depletion of Tregs induces resorption of the embryos in allogeneic matings in mice, ${ }^{26,28}$ whereas women with repeated spontaneous abortion show a decreased numbers of Tregs. ${ }^{29}$ Semen mediates the expansion of Tregs in DLN of the genital tract and their subsequent recruitment to the uterine endometrium. ${ }^{1,13}$ This tolerogenic response is induced even in the absence of conception, suggesting a major role for SP in eliciting this effect. ${ }^{11}$ Moreover, it was shown to be completely dependent on the presence of SVF, as mating with seminal vesicle-deficient males failed to induce the expansion of Tregs. ${ }^{11}$ It is generally assumed that Tregs not only suppress autoimmunity, but also control the course of pathogen-specific immunity in order to minimize associated tissue damage. ${ }^{30}$ However, the role of Tregs during the course of infectious processes remains unclear. Interestingly, using a mouse model of genital HSV-2 infection, Lund et al. ${ }^{31}$ have clearly shown that Tregs do not compromise the immune response against HSV-2, but rather they markedly improve the protective immune response to the infectious challenge by promoting the recruitment of immune cells into infected tissue. This observation suggests a possible link between the ability of SP to promote the local expansion of Tregs and our present results showing that SVF improves protection conferred by vaccination. The fact that we did not observe any increase in the frequency of Tregs at DLN at 30 days post vaccination with HSV-2 plus SVF perhaps reflects the transient nature of this response, as it was observed as early as 3.5 days after mating, and after this time Tregs appear to be recruited to the uterine endometrium. ${ }^{11}$

Figure 3 Seminal vesicle fluid (SVF) improves T cell memory response in draining lymph nodes (DLNs) of intravaginal route (IVAG) vaccinated mice. Groups of 10 medroxyprogesterone (Mp)-pretreated mice were vaccinated IVAG with inactivated HSV-2 $\left(1 \times 10^{4}\right.$ plaque forming unit (pfu) per $\left.15 \mu \mathrm{l}\right)$, without $(\mathrm{Im})$ or with SVF $(\mathrm{Im}+\mathrm{SVF})$, at a final SVF protein concentration of $5 \mathrm{mg} \mathrm{ml}^{-1}$. Thirty days later, mice were treated again with Mp and challenged IVAG with HSV-2 $\left(2 \times 10^{6}\right.$ pfu per $\left.15 \mu \mathrm{l}\right)$, and the DLN were obtained 3 days after challenge. Unvaccinated/unchallenged Mp-treated mice (C) were used as controls. (a) Total number of cells harvested from DLN/mouse. Results are expressed as the mean \pm s.d. of one of three different experiments. (b) Frequency of DLN CD4 + and CD8 + T cells in the gate of CD3 + cells. Representative dot plots are depicted. Total number of CD4 + and CD8 + T cells/ mouse is also shown. Results are expressed as the mean \pm s.e.m. of three different experiments. (c) DLN cells were labeled with carboxyfluorescein succinimidyl ester (CFSE), stimulated with UV-inactivated HSV-2 $\left(1 \times 10^{5}\right.$ pfu per $\left.200 \mu \mathrm{l}\right)$, and cultured for 5 days. Cell proliferation was analyzed by measuring the decrease in cell fluorescence by flow cytometry in the gate of CD4 + and CD8 + T cells. Representative dot plots and the mean $\pm \mathrm{s}$.e.m. of two different experiments are shown. (d) DLN cells were stimulated for $18 \mathrm{~h}$ with UV-inactivated HSV-2 (iHSV-2) or not (media) and interferon (IFN)- $\gamma$ producing cells were quantified by flow cytometry. Representative dot plots illustrate the production of IFN- $\gamma$ by unstimulated and iHSV-2 stimulated T cells in the gate of CD3 + cells. Bar graphs (right) represent the percentage of CD4 + and CD8 + T cells positive for the production of IFN- $\gamma$. Results are expressed as the mean \pm s.e.m. of three different experiments. (e) Cells were stimulated as in d with: iHSV-2, a pool of HSV-2 peptides specific for CD4 + and CD8 + T cells, UV-inactivated Vaccinia Virus or media. IFN- $\gamma$ producing cells were quantified by flow cytometry. Bar graphs represent the number of CD4 + and CD8 + T cells positive for the production of IFN- $\gamma / D L N s$ mouse. Results are expressed as the mean \pm s.e.m. of two different experiments. $(\mathbf{f}-\mathbf{i})$ In DLN cells cultured for 3 days with UV-inactivated HSV-2 $\left(1 \times 10^{6}\right.$ cells $\left./ 1 \times 10^{5} \mathrm{pfu}\right)$ we evaluated: (f) the production of interleukin (IL)-10 by enzyme-linked immunosorbent assay (mean \pm s.d., $n=3$ ), (g) the production of TGF- $\beta$ by quantitative PCR (qPCR; mean \pm s.d., $n=3$ ), (h) the frequency and number of FOXP3 + CD25 + CD4 + T cells by flow cytometry in cells cultured for an additional period of $18 \mathrm{~h}$ with PMA $\left(20 \mathrm{ng} \mathrm{ml}{ }^{-1}\right)$ and lonomycin $\left(1 \mu \mathrm{g} \mathrm{ml}^{-1}\right)$, and (i) the expression of CXCL9 and CXCL10 by qPCR. Results are expressed as the mean \pm s.e.m. of three different experiments. $\left({ }^{\star} P<0.05,{ }^{\star \star} P<0.01\right.$, and $\left.{ }^{\star \star *} P<0.001\right)$. 
a

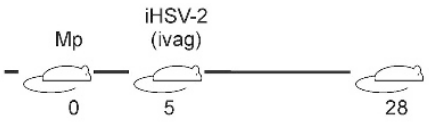

b

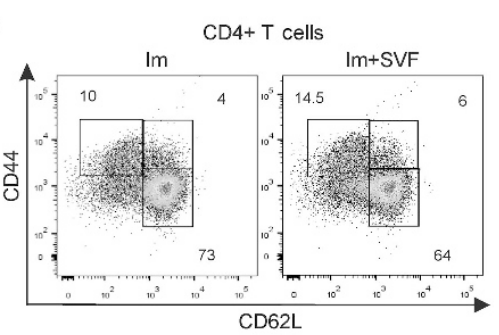

C

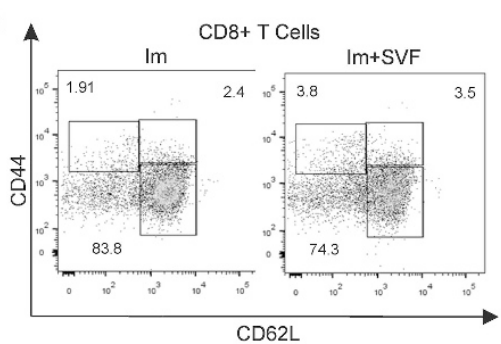

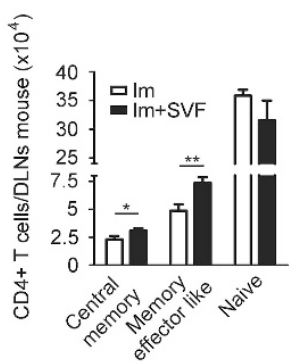

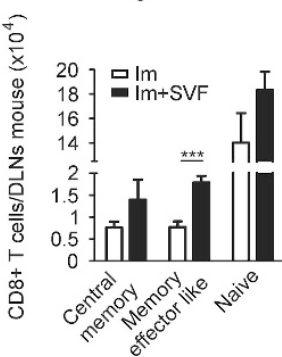

d
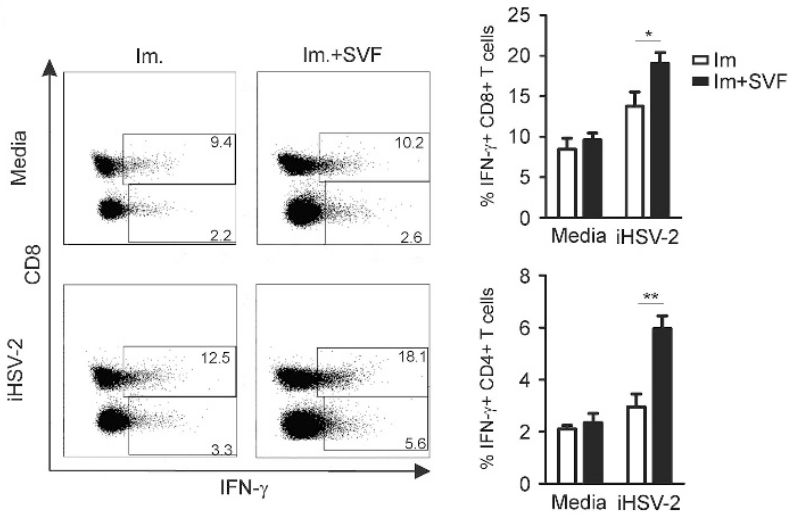

e

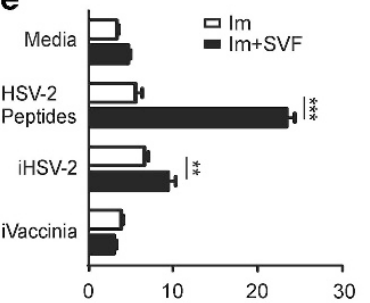

IFN- $\gamma+\mathrm{CD} 4 \mathrm{~T}$ cells/DLNs mouse $\left(\times 10^{3}\right)$
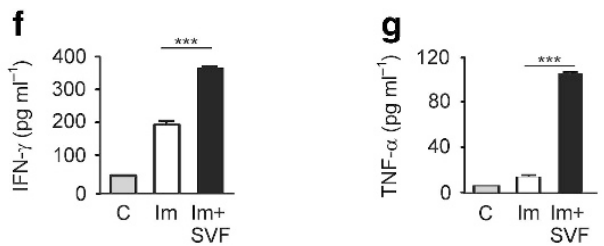

A large body of evidence indicates that the protective immune response against genital infection by HSV - 2 is strongly dependent on the induction of a memory $\mathrm{TH} 1$ response and the recruitment of viral-specific memory $\mathrm{CD} 4+$ and $\mathrm{CD} 8+\mathrm{T}$
Figure 4 Vaccination in the presence of seminal vesicle fluid (SVF) increases the CD4 + and CD8 + T cells memory response in draining lymph nodes (DLNs). Groups of 10 medroxyprogesterone (Mp)pretreated mice were vaccinated intravaginal route (IVAG) with inactivated HSV-2 $\left(1 \times 10^{4}\right.$ plaque forming unit (pfu) per $\left.15 \mu \mathrm{l}\right)$, in the absence $(\mathrm{Im})$ or presence of SVF (Im + SVF), at a final SVF protein concentration of $5 \mathrm{mg} \mathrm{ml}^{-1}$. Twenty-eight days later, DLN were recovered and cells were isolated and quantified (a). CD4 + (b) or CD8 + (c) T cells were analyzed by flow cytometry using CD44 and CD62L to differentiate central memory (CD44 ${ }^{\text {high }} \mathrm{CD} 62 \mathrm{~L}^{\text {high }}$ ), effector memory-like cells (CD44 ${ }^{\text {high }} C D 62 L^{\text {low }}$ ) and naive T cells (CD44 $\left.{ }^{\text {low }} \mathrm{CD} 62 \mathrm{~L}^{\text {high }}\right)$. Dot plots from a representative experiment (left) and the mean \pm s.e.m. of three different experiments (right) are shown. (d) DLN cells were stimulated for $18 \mathrm{~h}$ with UV-inactivated HSV-2 (iHSV-2) or not (media) and interferon (IFN)- $\gamma$ producing cells were quantified by flow cytometry. Representative dot plots illustrate the production of IFN- $\gamma$ by unstimulated and iHSV-2 stimulated T cells in the gate of CD3 + cells respectively within each T-cell population. Bar graphs (right) represent the percentage of CD4+ and $\mathrm{CD} 8+\mathrm{T}$ cells positive for the production of IFN- $\gamma$ respectively. Results are expressed as the mean \pm s.e.m. of three different experiments $(n=10$ mice per group). (e) Cells were stimulated as in $\mathbf{d}$ with: iHSV-2, a pool of HSV-2 peptides specific for CD4 + and CD8 + T cells, UV-inactivated Vaccinia virus or media. IFN- $\gamma$-producing cells were quantified by flow cytometry. Bar graphs represent the number of CD $4+$ and CD $8+$ T cells positive for the production of IFN- $\gamma /$ DLNs mouse. Results are expressed as the mean \pm s.e.m. of two different experiments. DLN cells were stimulated for $48 \mathrm{~h}$ with UV-inactivated HSV-2 and IFN- $\gamma$ (f) or tumor necrosis factor (TNF)- $\alpha(\mathbf{g})$ production was measured in cell supernatants by enzyme-linked immunosorbent assay. Results are expressed as the mean \pm s.d. $(n=3)\left({ }^{\star} P<0.05,{ }^{\star \star} P<0.01\right.$, and $\left.{ }^{\star \star \star} P<0.001\right)$.

cells into the genital tract. ${ }^{17,21,32-34}$ However, effective protection against HSV-2 infection as well as the induction of a protective immune response conferred by vaccination appears also to involve an important role for antibodies. ${ }^{35-38}$ These observations imply that the relative contribution of $\mathrm{T}$ and $\mathrm{B}$ cells in the immune response against HSV-2 might differ depending on the experimental settings. Our present results suggest that the adjuvant effect mediated by SVF is related to the improvement of a memory response mediated by $\mathrm{T}$ cells, but not $\mathrm{B}$ cells. In fact, we found no differences in the levels of vaginal and seric IgA and IgG antibodies between mice vaccinated with or without SVF.

We analyzed the T-cell response induced by IVAG vaccination by studying both, DLN and the vaginal mucosa. The analysis of DLN in mice vaccinated with inactivated HSV-2 plus SVF and then challenged with HSV-2 revealed a higher absolute number of $\mathrm{CD} 4+$ and $\mathrm{CD} 8+\mathrm{T}$ cells and a higher response of both $\mathrm{T}$ cell subsets in terms of cell proliferation and IFN- $\gamma$ production, when compared with mice vaccinated with inactivated HSV-2 alone. Similar observations were made by analyzing the site of viral replication, the vaginal mucosa. An increased presence of IFN- $\gamma$ and IL- 6 in vaginal washes, an enhanced production of IFN- $\gamma$, TNF- $\alpha$, IL- 6 , and IL-17A by whole vaginal cells, and a more pronounced infiltration of $\mathrm{CD} 8+\mathrm{T}$ cells was observed in mice vaccinated with inactivated HSV-2 plus SVF compared with those vaccinated with inactivated HSV-2 alone. Consistent with these findings, we found a higher frequency of central memory $\mathrm{T}$ cells $\left(\mathrm{CD} 44^{\text {high }} \mathrm{CD} 62 \mathrm{~L}^{\text {high }}\right)$ and effector memory-like $\mathrm{T}$ cells $\left(\mathrm{CD} 44^{\text {high }}{ }^{\mathrm{CD}} 62 \mathrm{~L}^{\text {low }}\right)$ in DLN from mice vaccinated with 

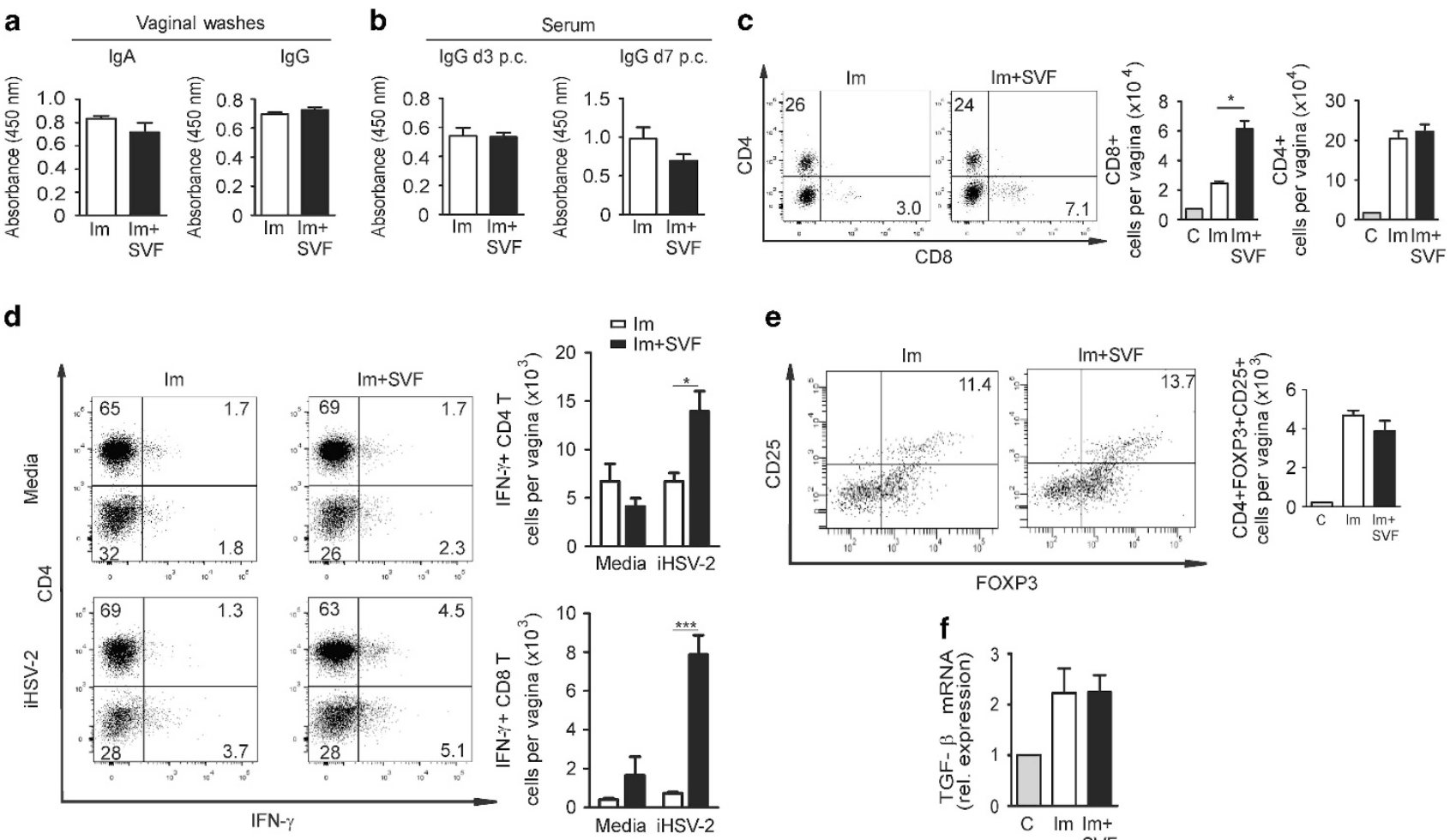

e

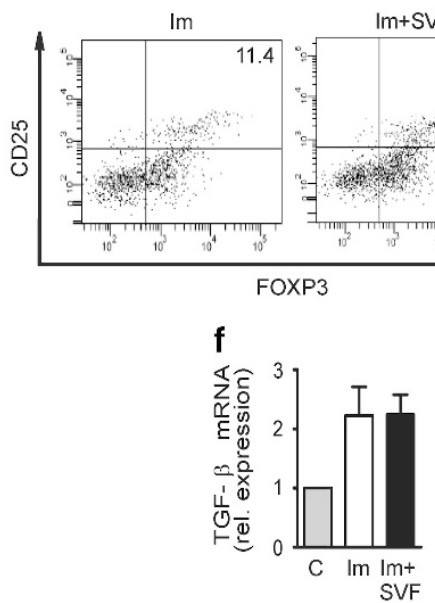

g

Vag. washes day 3 p.c.
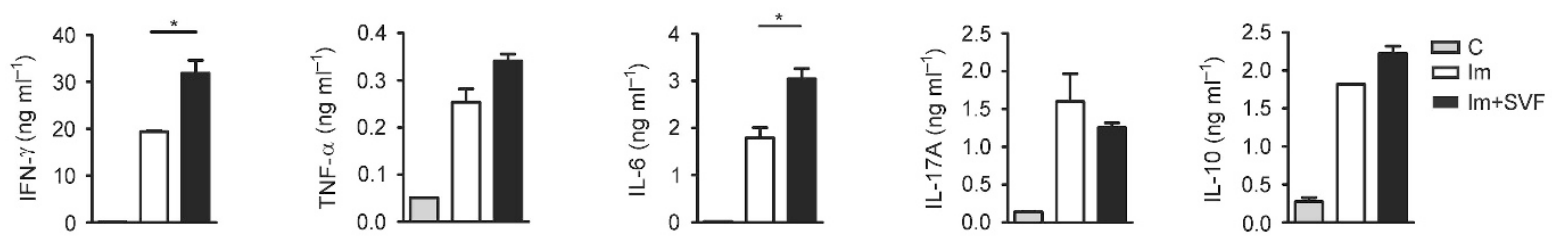

h

Vag. mucosa day 7 p.c.
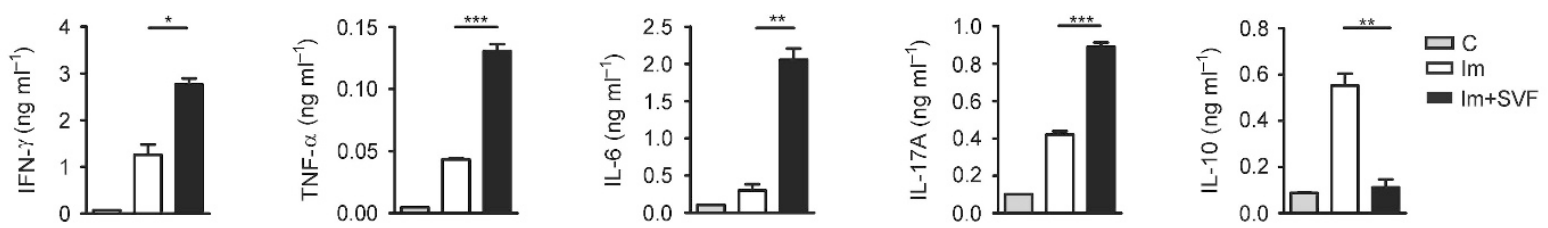

Figure 5 Seminal vesicle fluid (SVF) boosts a T-cell memory response in the vaginal mucosa of intravaginal route (IVAG) vaccinated mice. Groups of 10 medroxyprogesterone (Mp)-pretreated mice were vaccinated IVAG with inactivated HSV-2 $\left(1 \times 10^{4}\right.$ plaque forming unit (pfu) per $\left.15 \mu \mathrm{l}\right)$, without (Im) or with SVF (Im +SVF), at a final SVF protein concentration of $5 \mathrm{mg} \mathrm{ml}^{-1}$. Thirty days later, mice were treated again with Mp and challenged IVAG with $2 \times 10^{6}$ pfu per $15 \mu \mathrm{l}$. Unvaccinated/unchallenged Mp-treated mice (c) were used as controls. (a) Vaginal washes were obtained 3 days after challenging, and HSV-2 specific IgA and IgG antibodies were determined by enzyme-linked immunosorbent assay (ELISA) using a dilution of 1:5. (b) Serum samples were obtained at days 3 and 7 after challenging, and HSV-2-specific IgG antibodies were determined by ELISA, using a dilution of 1:10. (c) CD4 + and CD8 + T cells frequency in vaginal tissue obtained 3 days after challenging was assessed by fluorescence-activated cell sorting (FACS) in the gate of CD3 + cells. Representative dot plots (left) and the total number of CD8 + and CD4 + T cells in vaginal tissues (right) are shown. (d) Vaginal tissue IFN- $\gamma$ producing $T$ cells were analyzed by intracellular staining and flow cytometry 3 days after challenging. A representative dot plot and the number of $C D 4+$ and CD8 + T cells positive for IFN- $\gamma$ production per mouse are shown. In all cases, cells were re-stimulated in vitro for $18 \mathrm{~h}$ with inactivated HSV-2 (iHSV2) $\left(1 \times 10^{6}\right.$ cells per $\left.1 \times 10^{5} \mathrm{pfu}\right)$ or cultured with medium alone. (e) Vaginal cell suspensions obtained 3 days after challenging were cultured for $18 \mathrm{~h}$ with PMA $\left(20 \mathrm{ng} \mathrm{ml}^{-1}\right)$ and lonomycin $\left(1 \mu \mathrm{g} \mathrm{ml}^{-1}\right)$, and the frequency of FOXP3 + CD25 + CD4 + T cells was analyzed by flow cytometry. (f) Vaginal cell suspensions obtained 3 days after challenging were stimulated in vitro for $72 \mathrm{~h}$ with inactivated HSV-2 (iHSV-2) $\left(1 \times 10^{6}\right.$ cells per $1 \times 10^{5}$ pfu) or cultured with medium alone (c), and the expression of transforming growth dactor (TGF)- $\beta$ was analyzed by quantitative PCR. (g) The concentration of interferon (IFN)- $\gamma$, tumor necrosis factor (TNF)- $\alpha$, interleukin (IL)-6, IL-17A, and IL-10 was determined in vaginal washes, obtained 3 days after challenging, by ELISA assay. (h) Vaginal cell suspensions, obtained 7 days after challenging were cultured with inactivated HSV $-2\left(1 \times 10^{6}\right.$ cells per $1 \times 10^{5}$ pfu $)$ for $72 \mathrm{~h}$ and the concentrations of IFN- $\gamma$, TNF- $\alpha$, IL-6, IL-17A, and IL-10 were determined by ELISA assay. Results are expressed as the mean \pm s.e.m. of 10 mice per group $(\mathrm{A}-\mathrm{F})$ or as the mean \pm s.d. of three different experiments $(\mathbf{g}$ and $\mathbf{h})\left({ }^{\star} P<0.05\right.$, ${ }^{\star \star} P<0.01$, and $\left.{ }^{* \star *} P<0.001\right)$. 
a

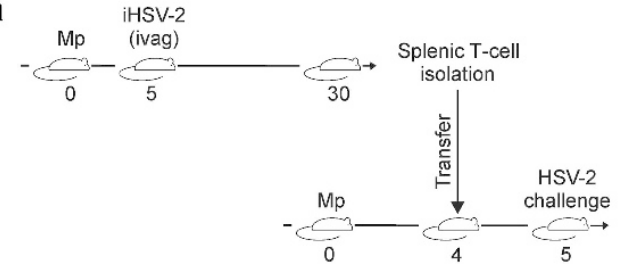

b
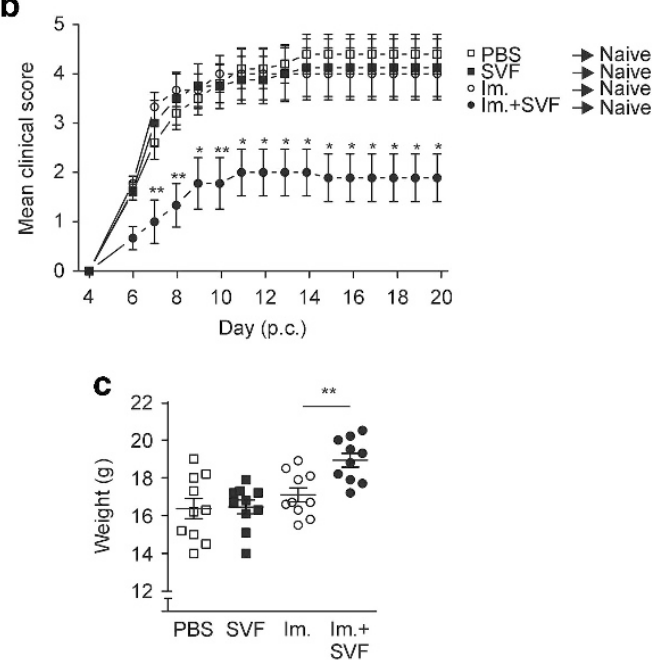

d

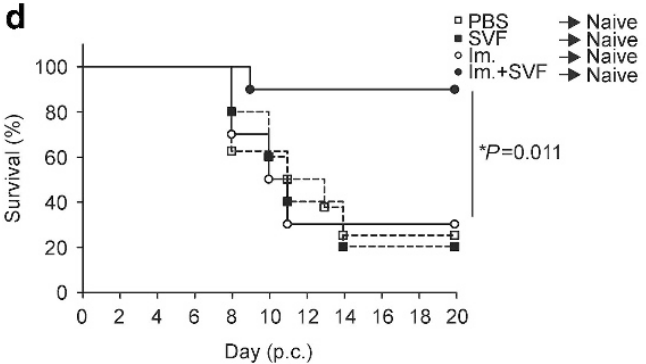

Figure 6 Adoptive transfer of splenic T cells from mice vaccinated by intravaginal route (IVAG) with inactivated HSV-2 plus seminal vesicle fluid (SVF) confers a higher protection against a lethal challenge compared with T cells from mice vaccinated with inactivated HSV-2 alone. Groups of 10 medroxyprogesterone (Mp)-pretreated mice were inoculated IVAG with: (a) phosphate-buffered saline-bovine serum albumin (PBS-BSA) $\left(5 \mathrm{mg} \mathrm{ml}^{-1}\right)$ (PBS), (b) SVF $\left(5 \mathrm{mg} \mathrm{ml}^{-1}\right)$, (c) inactivated HSV-2 (iHSV-2) $\left(1 \times 10^{4}\right.$ plaque forming unit (pfu) per $\left.15 \mu \mathrm{l}\right)(\mathrm{Im})$, or $(\mathrm{d})$ inactivated HSV-2 (iHSV-2) $\left(1 \times 10^{4}\right.$ pfu per $\left.15 \mu \mathrm{l}\right)$ plus SVF $(\mathrm{Im}+\mathrm{SVF})$, at a final SVF protein concentration of $5 \mathrm{mg} \mathrm{ml}^{-1}$. Thirty days later, mice for all four groups were killed and spleens were recovered. CD4 + and CD8 + T cells were purified and five million of total T cells (CD4:CD8 T cell ratio of 3:2) were transferred to Mp-pretreated mice by retro orbital inoculation. Mice were challenged with HSV-2 $\left(2 \times 10^{6}\right.$ pfu per $\left.15 \mu \mathrm{l}\right) 18 \mathrm{~h}$ later, as indicated in (a), and were examined daily for their clinical score (b), weight (at day 7 post challenging) (c), and survival (d). Results are expressed as the mean \pm s.e.m. of the clinical score (b), weight (c), or as the survival (d) of 10 mice per each group. Data from a representative experiment $(n=2)$ are shown $\left({ }^{\star} P<0.05\right.$ and $\left.{ }^{* *} P<0.01\right)$.

inactivated HSV-2 plus SVF, at 28 days after vaccination, before challenging. Of note, the adoptive transfer of splenic $\mathrm{T}$ cells from mice vaccinated with inactivated HSV-2 plus SVF to naive mice provided a much higher protection compared with $\mathrm{T}$ cells isolated from mice vaccinated with inactivated virus alone, further supporting that the enhanced protection conferred by
SVF is mediated by the induction of a memory response mediated by $\mathrm{T}$ cells.

How SVF boosts the induction of a memory T-cell response remains unclear. We hypothesize that the ability of semen to induce an early inflammatory response in the female genital tract provides the adequate environment for the priming of a protective immune response. Robertson and colleagues ${ }^{39}$ have shown that acting on epithelial cells, SP induces the activation of an acute inflammatory response in the cervix, resulting in the production of monocyte chemoattractant protein-1, granulocyte-macrophage colony-stimulating factor, IL-6, and IL-8. Consistent with these observations made in mouse models, serial analysis of human cervical samples revealed that semen deposition induces a similar inflammatory response, consisting in the infiltration of the cervix by macrophages, DCs, and memory $\mathrm{T}$ cells, together with an increased production of inflammatory cytokines, such as IL- $1 \alpha$, IL- 6 , IL- 8 , and colony stimulating factor $2 .{ }^{4,8}$ The role of this postcoital inflammatory response is not clear; however, it is thought to have a role in promoting fertility. ${ }^{1}$ We analyzed whether SVF promoted an acute inflammatory response when administered together with the vaccine (inactivated HSV-2), by analyzing the production of cytokines by vaginal cell suspensions and DLN cells at early time points, i.e., at $48 \mathrm{~h}$ post immunization. We found that immunization with inactivated HSV-2 plus SVF resulted in the production of higher levels of IFN- $\gamma$, TNF- $\alpha$, and IL- 6 , compared with mice immunized with inactivated-HSV-2 alone. Interestingly, this response was shown to be associated with an increase recruitment of natural killer cells in the vaginal mucosa, an enhanced expression of CD86 by vaginal DCs and a marked increase in the frequency of DCs in DLN. As the recognized ability of IFN- $\gamma$ to promote the differentiation of $\mathrm{CD} 4+\mathrm{T}$ cells into a TH1 profile ${ }^{40}$ and the development of a memory response mediated by CD $8+\mathrm{T}$ cells, ${ }^{41}$ we speculate that through the stimulation of IFN- $\gamma$ production and the recruitment of fully mature DCs in DLN, SVF might promote both, the differentiation of $\mathrm{CD} 4+\mathrm{T}$ cells into a TH1 profile and the expansion of memory CD8 $+\mathrm{T}$ cells, two processes that represent the basis for the protective immune response against HSV-2 infection.

A weakness of our study is that we did not analyze whether mating, instead of administration of SVF, improves protection conferred by vaginal vaccination. However, it is not possible to administrate the vaccine at the time of mating. An alternative approach might involve the administration of the vaccine before mating. However, the amount of virus remains inside the vagina in mated and unmated mice could be different. Another reason why it is not possible to investigate immunomodulatory effects in naturally mated females is that they will not mate when the hormone status is modified by Mp administration, which is necessary to ensure viral infectivity. ${ }^{42}$ Moreover, the possibility that the administration of $\mathrm{Mp}$ might affect female tract responsiveness to seminal fluid immune regulatory compounds should not be ruled out. Finally, it should be considered that our experiments were performed with SVF and not with whole seminal fluid. Although SVF is the 

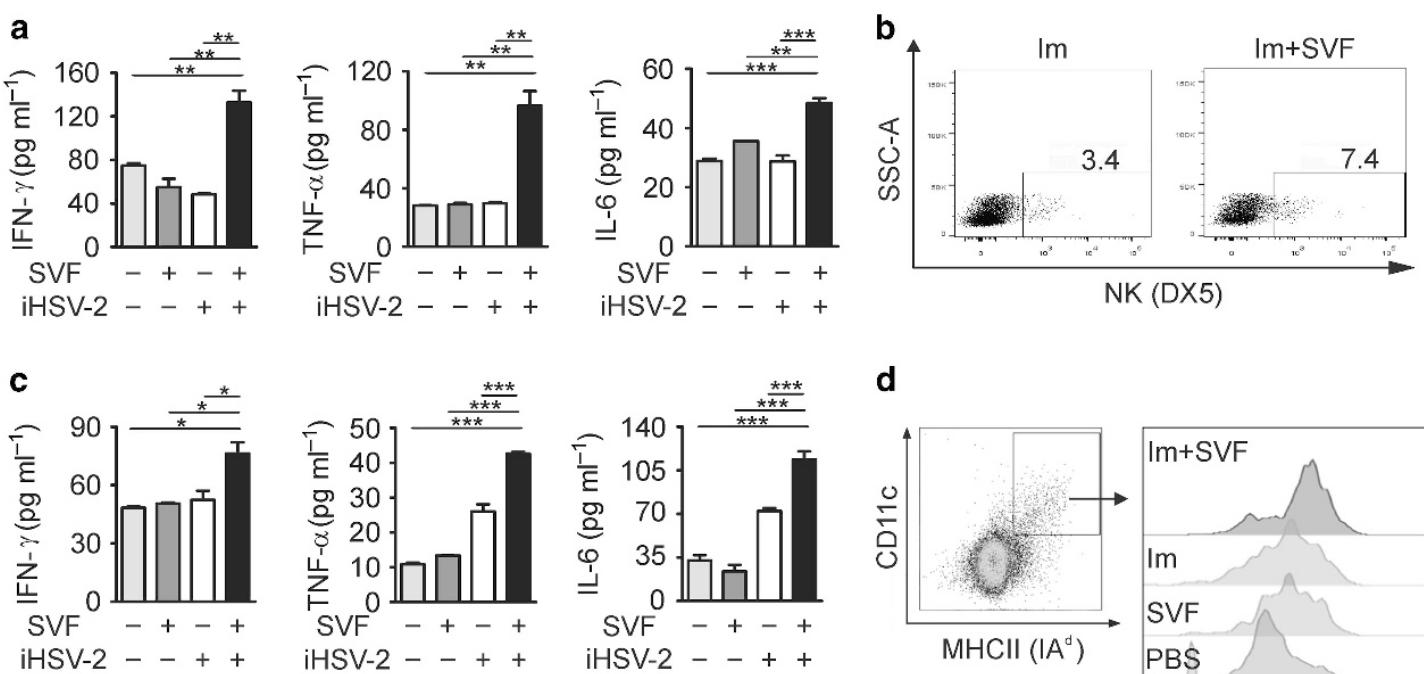

d
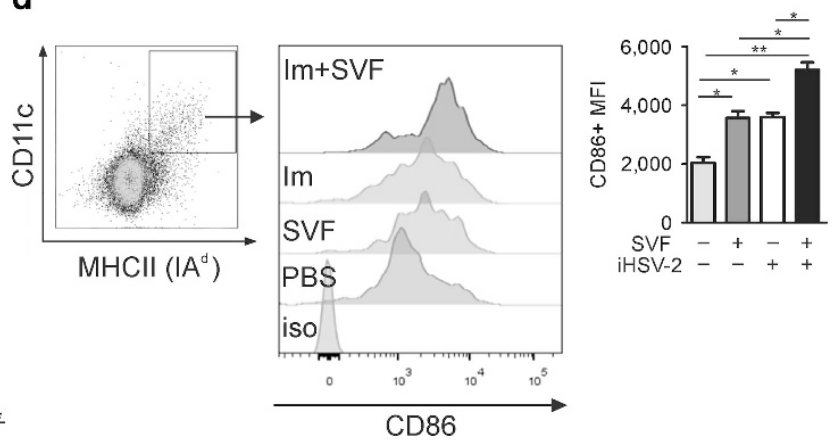
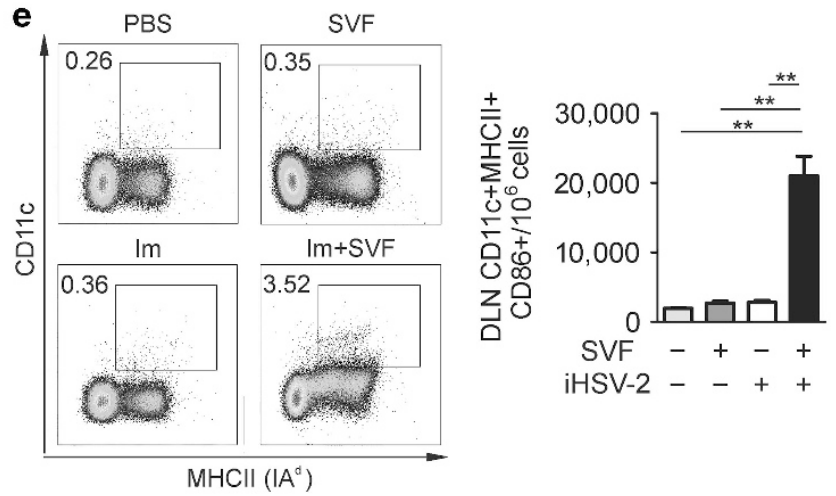

Figure 7 Vaccination in the presence of seminal vesicle fluid (SVF) boosts an early local inflammatory response. Groups of five medroxyprogesterone (Mp)-pretreated mice were vaccinated intravaginal route (IVAG) with inactivated HSV-2 $\left(1 \times 10^{4}\right.$ plaque forming unit (pfu) per $15 \mu$ l), in the absence or presence of SVF, at a final SVF protein concentration of $5 \mathrm{mg} \mathrm{ml}^{-1}$. Forty-eight hours later, vaginal tissues and draining lymph nodes (DLNs) were recovered. (a) The production of interferon (IFN)- $\gamma$, tumor necrosis factor (TNF)- $\alpha$, and interleukin (IL)- 6 in vaginal cell suspensions cultured in medium for $48 \mathrm{~h}$ was evaluated by enzyme-linked immunosorbent assay (ELISA). (b) The frequency of natural killer cells (DX5 + cells) was analyzed by flow cytometry. (c) The production of IFN- $\gamma$, TNF- $\alpha$, and IL- 6 in DLN cells cultured in medium for $48 \mathrm{~h}$ was determined by ELISA assay. (d) The expression of CD86 in vaginal DCs (CD11c + MHCII $\left(I A^{d}\right)+$ cells) was evaluated by flow cytometry and the mean \pm s.e.m. $(n=2)$ is shown. (e) The frequency of DCs $(\mathrm{CD} 11 \mathrm{c}+\mathrm{MHClI}(\mathrm{IA})+$ cells) in DLN cells was evaluated by flow cytometry. The average number of CD86 + DCs per million of DLN cells is also shown. Results in a, c, d right panel, and e right panel are expressed as the mean \pm s.d. (1 representative of three experiments). ( ${ }^{\star} P<0.05$, ${ }^{\star \star} P<0.01$, and $\left.{ }^{* * *} P<0.001\right)$.

major component of rodent seminal fluid, whole SP contains sperm, and secretions from the epididymis and other male accessory sex glands. It is unlikely, but cannot be excluded, that additional factors in whole intact SP could attenuate the immune regulatory function of SVF described in this study.

The mechanisms underlying the adjuvant effect of SVF remain to be characterized. SVF contains a diverse array of components, including lipids, carbohydrates, peptides, proteins, cytokines, and chemokines, ${ }^{5-9}$ able to mediate a variety of effects on both HSV-2 infectivity and the immune response against HSV-2. In agreement with previous observations performed with SP, ${ }^{15}$ we found that SVF does not modify the course of HSV-2 primary infection in mice. On the other hand, contrasting with our observations indicating that mouse SVF does not affect in vitro HSV-2 infectivity, Torres et al. ${ }^{43}$ have reported that human SP enhances in vitro HSV-2 infectivity, suggesting that secretions from the epididymis and other male accessory sex glands might be responsible for this enhancing effect.

In this study we show for the first time that SVF boosts a memory $\mathrm{T}$-cell response induced by vaccination against a sexual transmitted pathogen, markedly improving protection against a lethal challenge. Our observations suggest that the adjuvant effect mediated by SVF might be related to its ability to induce an early inflammatory response in the female genital tract providing an adequate environment for the priming of a protective immune response mediated by both TH1 and CD8 + T cells. Based on the observations made by Robertson and colleagues, ${ }^{8}$ suggesting that TGF- $\beta$ promotes an acute inflammatory response in the receptive mucosa, we are currently analyzing the possible role of TGF- $\beta$ as an adjuvant at the female genital tract. Our results raise a number of questions. For example, would a similar protective effect be induced for other sexually transmitted pathogens? Would similar mechanisms be induced in women after unprotected 
sexual intercourse? Experiments addressing these questions may lead to a better comprehension of the immune response against sexually transmitted infectious diseases providing a more rational basis for the development of mucosal vaccines.

\section{MATERIALS AND METHODS}

Mice and viruses. Female BALB/c 8- to 10 -wk-old mice were used in all experiments. Mice were acquired from the School of Veterinary Sciences Central Animal House (University of Buenos Aires) and were housed in our animal facilities. Animal care and all experiments were done in compliance with legal and institutional guidelines. These studies were approved by the ethical committee for animal experiments (High Medical School, University of Buenos Aires). HSV-2 G-strain was a gift from Dr C. Pujol (Natural Sciences School, University of Buenos Aires). Vero cells were purchased from the American Type Culture Collection (Manassas, VA) and cultured in DMEM (Thermo Scientific, Waltham, MA) supplemented with $10 \%$ heat-inactivated fetal bovine serum, penicillin $\left(100 \mathrm{U} \mathrm{ml}^{-1}\right)$, and streptomycin $\left(100 \mu \mathrm{g} \mathrm{ml}^{-1}\right)$. HSV-2 was propagated and titrated in Vero cells as described previously ${ }^{44}$ and the infectious titer was expressed as pfu per ml. For vaccination, the whole virus was inactivated by UV light exposure for $30 \mathrm{~min}$. Vaccinia virus (Western Reserve strain), granted by Dr M. Gherardi, was inactivated by UV light exposure for $30 \mathrm{~min}$ and used for in vitro stimulation of T cells $\left(1 \times 10^{6}\right.$ cells per $\left.1 \times 10^{5} \mathrm{pfu}\right)$.

SVF extraction. Donor males were caged in groups (five mice per cage). Seminal vesicle glands were excised from 9- to 11-week-old $\mathrm{BALB} / \mathrm{c}$ males immediately after sacrifice in sterile conditions. Special care was taken to blunt dissect and exclude the closely associated coagulation gland from seminal vesicle gland excision and fluid preparation. SVF of 10 mice was pooled, diluted in PBS at a final protein concentration of $12 \mathrm{mg} \mathrm{ml}^{-1}$, and freshly used for immunizations. When it was necessary, SVF was stored at $-80^{\circ} \mathrm{C}$ until use.

Inoculation of SVF, immunizations, and viral challenge. Considering that the mouse ejaculate volume is $2-4 \mu \mathrm{l}^{19}$ and the total protein concentration of mouse SVF is around $21 \mathrm{mg} \mathrm{ml}^{-1}$ (ref. 20), the amount of protein deposited into the vaginal tract during natural coitus could be estimated in the range of 42 to $84 \mu$ g. To approximate as closely as possible to natural coitus, in our experimental model mice were inoculated IVAG with $15 \mu \mathrm{l}$ of a solution containing a final SVF protein concentration of $5 \mathrm{mg} \mathrm{ml}^{-1}$. This procedure results in the deposition of $75 \mu \mathrm{g}$ of SVF proteins into the vagina, an amount similar to that observed in the course of natural coitus.

Female mice were injected subcutaneously in the neck ruff with Mp (König, Buenos Aires, Argentina, $2 \mathrm{mg}$ per mouse in $200 \mu \mathrm{l}$ of PBS). Five days later, mice were inoculated IVAG with a $15 \mu \mathrm{l}$ volume containing: (a) PBS-BSA $\left(5 \mathrm{mg} \mathrm{ml}^{-1}\right)$, (b) SVF $\left(5 \mathrm{mg} \mathrm{ml}^{-1}\right)$, (c) $10^{4} \mathrm{pfu}$ of inactivated HSV-2 in PBS, supplemented with SVF $\left(5 \mathrm{mg} \mathrm{ml}^{-1}\right)$, or (d) $10^{4} \mathrm{pfu}$ of inactivated HSV-2 in PBS, supplemented with BSA $\left(5 \mathrm{mg} \mathrm{ml}^{-1}\right)$. Thirty days later, mice were treated again with $\mathrm{Mp}$ as described above, and after five days mice were challenged IVAG with $2 \times 10^{6}$ pfu of HSV-2 in $15 \mu \mathrm{l}$ of PBS. HSV-2infected mice were examined daily for vaginal inflammation and neurological illness. The severity of disease was scored as follows: ${ }^{45} 0$, no sign; 1 , slight genital erythema and edema; 2, moderate genital inflammation; 3 , purulent genital lesions; 4 , hind limb paralysis; and 5, premoribund. Owing to ethical concerns, animals were killed before reaching the moribund state. For primary infection studies, mice were treated with Mp and 5 days later challenged IVAG with a $15 \mu$ l volume containing $1 \times 10^{5}$ or $2 \times 10^{6} \mathrm{pfu}$ of $\mathrm{HSV}-2$ in $15 \mu \mathrm{l}$ of PBS, supplemented with SVF or BSA, at a final protein concentration of $5 \mathrm{mg} \mathrm{ml}^{-1}$.

Sample collection and processing. Vaginal fluid was collected from anesthetized mice (Ketamine $12,5 \mathrm{mg} \mathrm{ml}^{-1}$-Xylacine $1,25 \mathrm{mg} \mathrm{ml}^{-1}$,
Richmond, Buenos Aires, Argentina), by washing the vagina two times with $35 \mu \mathrm{l}$ of sterile PBS plus protease inhibitors. Vaginal washed samples were pooled, centrifuged at 3,000 r.p.m. for $15 \mathrm{~min}$ at $4{ }^{\circ} \mathrm{C}$, and supernatants were collected and stored at $-80^{\circ} \mathrm{C}$ until use. Serum samples were obtained by cardiac puncture from mouse under deep terminal anesthesia. Cell suspensions from iliac lymph nodes (DLN) and vaginal tracts were obtained as described previously. ${ }^{46}$ Briefly, DLN and vaginal tracts were recovered under sterile conditions from mice killed by cervical dislocation. DLN cell suspensions were obtained by disaggregating the tissue through a $40 \mu \mathrm{m}$ cell strainer (BD Biosciences, San Diego, CA) and then washed three times with PBS supplemented with $5 \%$ heat-inactivated fetal bovine serum. The genital tracts of vagina were segregated from urethra and cervix, cut into small pieces, and incubated for $45 \mathrm{~min}$ in culture medium supplemented with collagenase IV $\left(0.2 \mathrm{mg} \mathrm{ml}^{-1}\right.$; Thermo Scientific) and DNAse I ( $25 \mathrm{U} \mathrm{ml}^{-1}$; Sigma-Aldrich, St Louis, MO). Samples were further disaggregated through a $70 \mu \mathrm{m}$ cell strainer and washed two times with PBS supplemented with $5 \%$ heat-inactivated fetal bovine serum. Cell cultures were performed in RPMI 1640 medium (Thermo Scientific), supplemented with $10 \%$ heat-inactivated fetal bovine serum, $2 \mathrm{~mm}$ L-glutamine, $100 \mathrm{U} \mathrm{ml}^{-1}$ penicillin, $100 \mu \mathrm{g} \mathrm{ml}^{-1}$ streptomycin, $10 \mathrm{~mm}$ HEPES (Thermo Scientific) and $55 \mu \mathrm{M}$ 2-mercaptoethanol (Thermo Scientific).

Measurement of cytokine production. Cytokines were measured in vaginal washes and in cell cultures from DLN and vaginal cell suspensions. The production of IFN- $\gamma$, TNF- $\alpha$, IL-6, IL-10, and IL-17A was measured by enzyme-linked immunosorbent assay following the manufacturer's instructions (Biolegend, San Diego, CA). IFN- $\gamma$ was also measured by intracellular staining and flow cytometry in permeabilized cells, previously treated for $4 \mathrm{~h}$ with Brefeldin A $\left(10 \mu \mathrm{g} \mathrm{ml}^{-1}\right.$, GolgiPlug, BD Biosciences). For stimulation, cells were cultured with UV-inactivated HSV-2 $\left(1 \times 10^{6}\right.$ cells per $\left.1 \times 10^{5} \mathrm{pfu}\right)$ at times indicated in figures. Also, T CD4 $+\mathrm{HSV}-2$-specific peptides (NLPVLDQL (gpD) and KDVTVSQVWFGHRYSQ (gpB)), and T CD8 + HSV-2-specific peptides (HGPSLYRTF (ICP27) and KMADPNRFRGK (gpD) $)^{47,48}$ were pooled and used at a final concentration of $25 \mu \mathrm{g}$ each every $1 \mathrm{~m}$ cells and incubated $18 \mathrm{~h}$. Concavalin A (positive control), medium alone (negative control) and $\mathrm{UV}$-inactivated vaccinia virus $\left(1 \times 10^{6}\right.$ cells per $\left.1 \times 10^{5} \mathrm{pfu}\right)$ were also used for stimulation.

Analysis of TGF- $\beta$, CXCL9, and CXCL10 production by quantitative PCR. Total RNA was obtained from $3 \times 10^{6}$ cells lysed with TRIzol (Thermo Scientific). Reverse transcription was carried out using Moloney murine leukemia virus reverse transcriptase (Invitrogen) according to the manufacturer's instructions. In brief, $5 \mu \mathrm{g}$ of RNA were incubated for $50 \mathrm{~min}$ at $37^{\circ} \mathrm{C}$ in the presence of $200 \mathrm{ng}$ random decamer primers (Invitrogen) and $10 \mathrm{~mm}$ dNTP mix. Quantitative real-time PCR was performed using SYBR Green PCR Master Mix (Invitrogen) in $20 \mu \mathrm{l}$ reaction. All primers were used at a concentration of $300 \mathrm{~nm}$ (except for CXCL10; $50 \mathrm{~nm} \mathrm{F,} 900 \mathrm{~nm} \mathrm{R}$ ). ${ }^{49}$ Primers for CXCL9 were $5^{\prime}$-TTTTCCTTTTGGGCATCATCTT-3' (forward) and $5^{\prime}$-AGCATCGTGCATTCCTTATCACT-3' (reverse); for CXCL10 $5^{\prime}$-GAAATCATCCCTGCGAGCCT-3' (forward) and $5^{\prime}$-TTGATGG TCTTAGATTCCGGATTC- $3^{\prime}$ (reverse); and for TGF- $\beta 5^{\prime}$-AATTCC TGGCGTTACCTTGG-3' (forward) and $5^{\prime}$-ATCGAAAGCCCTGTA TTCCG-3' (reverse); for HPRT $5^{\prime}$-ATCATTATGCCGAGGATTTG GAA- $3^{\prime}$ (forward) and 5' ${ }^{\prime}$-TTGAGCACACAGAGGGCCA-3' (reverse); and for $\beta$-actin $5^{\prime}$-TGTCCACCTTCCAGCAGCAGATGT$3^{\prime}$ (forward) and 5'-AGCTCAGTAACAGTCCGCCTAGA-3 ${ }^{\prime}$ (reverse). Reactions were carried out in StepONE Plus cycler (Thermo Scientific). The cycling program used was $95^{\circ} \mathrm{C}$ for $10 \mathrm{~min}$ followed by 40 cycles of $95^{\circ} \mathrm{C}$ for $15 \mathrm{~s}$ and $60^{\circ} \mathrm{C}$ for $60 \mathrm{~s}$. Data were analyzed by the $\Delta \Delta \mathrm{Ct}$ method using HPRT or actin as reference gene.

Adoptive transfer of $\mathbf{T}$ cells. Balb/c female mice were inoculated IVAG with PBS-BSA $\left(5 \mathrm{mg} \mathrm{ml}^{-1}\right)$, SVF $\left(5 \mathrm{mg} \mathrm{ml}^{-1}\right)$, inactivated 
HSV-2 $\left(10^{4}\right.$ pfu per $\left.15 \mu \mathrm{l}\right)$, or inactivated HSV-2 $\left(10^{4}\right.$ pfu per $\left.15 \mu \mathrm{l}\right)$ plus SVF $\left(5 \mathrm{mg} \mathrm{ml}^{-1}\right)$. After 30 days, spleens were removed and $\mathrm{CD} 4+$ and CD8 + T cells were purified using magnetic-activated cell separation columns and negative selection (Miltenyi Biotec, Auburn, $\mathrm{CA}$ ). The selected CD $4+$ or CD $8+\mathrm{T}$ cells ( $>90 \%$ purity) were carboxyfluorescein succinimidyl ester labeled and transferred using a CD4/CD8 T-cell ratio of 3:2. A total of five million purified T cells were transferred to each mouse by retro orbital injection in Mp-treated Balb/c-naive recipients. Carboxyfluorescein succinimidyl ester label was analyzed in blood recovered from mice tail tip as an internal control. Eighteen hours after transfer, mice were challenged IVAG with $2 \times 10^{6} \mathrm{pfu}$ per $15 \mu \mathrm{l} \mathrm{HSV}-2$ virus, and survival and disease progression were evaluated.

HSV-2-specific antibody measurements. HSV-2-specific IgG and IgA were measured in vaginal washes and/or serum samples by enzyme-linked immunosorbent assay. Briefly, Greiner 96F microwell plates (Greiner Bio-One Monroe, NC) were coated with $100 \mu \mathrm{l}$ of the whole inactivated HSV-2 lysate $\left(5 \mu \mathrm{g} \mathrm{ml}^{-1}\right)$ overnight at $4{ }^{\circ} \mathrm{C}$ in $0.05 \mathrm{M}$ carbonate buffer and p 9. H6. The plates were blocked with $2 \%$ BSA in PBS for $1 \mathrm{~h}$ in $37^{\circ} \mathrm{C}$. Serial dilutions of samples were incubated for $1 \mathrm{~h}$ at $37^{\circ} \mathrm{C}$. After washing with $0.05 \%$ Tween 20 , the plates were incubated for $1 \mathrm{~h}$ at $37^{\circ} \mathrm{C}$ with goat anti-mouse IgG or goat anti-mouse IgA coupled to horseradish peroxidase (Jackson Immuno Research, West Grove, PA) in PBS supplemented with 1\% BSA and revealed using TMB substrate reagent (BD Biosciences). Absorbance was then measured at $450 \mathrm{~nm}$.

Proliferation assay. To evaluate cell proliferation induced by HSV-2, DLN cells were labeled with $1 \mathrm{~mm}$ carboxyfluorescein succinimidyl ester (Thermo Scientific), according to the manufacturer's instructions. Cells were cultured in U-bottom 96-well plates (Greiner Bio-One) for 5 days with medium alone or with whole UV-inactivated HSV-2. Then, cells were collected, washed, and stained for $20 \mathrm{~min}$ at $4{ }^{\circ} \mathrm{C}$ with phycoerythrin-labeled anti-mouse $\mathrm{CD} 3$, allophycocyanin-labeled anti-mouse CD4, and PerCP-labeled anti-mouse CD8 (BD Biosciences), and cellular proliferation was assayed by flow cytometry.

Flow cytometry assays. Fluorescein isothiocyanate, PE, PerCP, or APC-conjugated monoclonal antibodies directed to CD3, CD4, CD8, CD11c, DX5, IAd, FOXP3, CD25, CD44, CD62L, and IFN- $\gamma$ were obtained from $\mathrm{BD}$ Bioscience. In all cases, isotype-matched control antibodies were used and a gate (R1) was defined in the analysis to exclude nonviable cells and debris, based on size and propidium iodine staining. Analyses were performed by using a fluorescenceactivated cell sorting flow cytometer (FACS CANTO I, BD Biosciences) and the data were analyzed using FlowJo software (Tree Star, Ashland, OR).

Statistics. Student paired $t$-test was used to determine the significance of differences between groups. Multiple analyses were followed by Bonferroni's multiple-comparison post test. Gehan-Breslow-Wilcoxontest was performed for survival analysis. $P$-values $<0.05$ were considered statistically significant.

SUPPLEMENTARY MATERIAL is linked to the online version of the paper at http://www.nature.com/mi

\section{ACKNOWLEDGMENTS}

This study was supported by grants from the Consejo Nacional de Investigaciones Científicas y Técnicas (CONICET), the Agencia Nacional de Promoción Científica y Tecnológica (Argentina), GlaxoSmithKline, and Universidad de Buenos Aires (20020150100178BA). We thank Dr Magdalena Gherardi, Dra Ana Rodriguez, Dra Mónica Vermeulen, and Dr Norberto Sanjuan for technical assistance.

\section{AUTHOR CONTRIBUTIONS}

Conceptualization: A.C.; A.V., F.R.L. and J.G. Methodology: A.V., C.M. and A.C. Investigation: A.V., F.R.L., G.E., A.P., M.G.P. and A.C. Formal analysis:
A.V. and E.D. Writing-original draft: A.C. and A.V. Writing-review and editing: A.C., J.G., F.R.L. and J.S. Funding acquisition: A.C. Resources: A.V., A.M., S.S. and M.P.H. Supervision: A.C. and J.G.

\section{DISCLOSURE}

The authors declared no conflict of interest.

c) 2018 Society for Mucosal Immunology

\section{REFERENCES}

1. Robertson, S.A., Prins, J.R., Sharkey, D.J. \& Moldenhauer, L.M. Seminal fluid and the generation of regulatory Tcells for embryo implantation. Am. J. Reprod. Immunol. 69, 315-330 (2013).

2. Doncel, G.F., Anderson, S. \& Zalenskaya, I. Role of semen in modulating the female genital tract microenvironment-implications for HIV transmission. Am. J. Reprod. Immunol. 71, 564-574 (2014).

3. Shima, T. et al. Paternal antigen-specific proliferating regulatory $T$ cells are increased in uterine-draining lymph nodes just before implantation and in pregnant uterus just after implantation by seminal plasma-priming in allogeneic mouse pregnancy. J. Reprod. Immunol. 108, 72-82 (2015).

4. Sharkey, D.J., Tremellen, K.P., Jasper, M.J., Gemzell-Danielsson, K. \& Robertson, S.A. Seminal fluid induces leukocyte recruitment and cytokine and chemokine mRNA expression in the human cervix after coitus. J. Immunol. 188, 2445-2454 (2012).

5. Owen, D.H. \& Katz, D.F. A review of the physical and chemical properties of human semen and the formulation of a semen simulant. J. Androl. 26, 459-469 (2005).

6. Pilch, B. \& Mann, M. Large-scale and high-confidence proteomic analysis of human seminal plasma. Genome Biol. 7, R40 (2006).

7. Politch, J.A., Tucker, L., Bowman, F.P. \& Anderson, D.J. Concentrations and significance of cytokines and other immunologic factors in semen of healthy fertile men. Hum. Reprod. 22, 2928-2935 (2007).

8. Sharkey, D.J., Macpherson, A.M., Tremellen, K.P., Mottershead, D.G., Gilchrist, R.B. \& Robertson, S.A. TGF-beta mediates proinflammatory seminal fluid signaling in human cervical epithelial cells. J. Immunol. 189, 1024-1035 (2012).

9. Templeton, A.A., Cooper, I. \& Kelly, R.W. Prostaglandin concentrations in the semen of fertile men. J. Reprod. Fertil. 52, 147-150 (1978).

10. Sharkey, D.J., Macpherson, A.M., Tremellen, K.P. \& Robertson, S.A. Seminal plasma differentially regulates inflammatory cytokine gene expression in human cervical and vaginal epithelial cells. Mol. Hum. Reprod. 13, 491-501 (2007).

11. Guerin, L.R., Moldenhauer, L.M., Prins, J.R., Bromfield, J.J., Hayball, J.D. \& Robertson, S.A. Seminal fluid regulates accumulation of FOXP3 + regulatory $T$ cells in the preimplantation mouse uterus through expanding the FOXP3 + cell pool and CCL19-mediated recruitment. Biol. Reprod. 85, 397-408 (2011).

12. Remes Lenicov, F. et al. Semen promotes the differentiation of tolerogenic dendritic cells. J. Immunol. 189, 4777-4786 (2012).

13. Merlotti, A. et al. Fucosylated clusterin in semen promotes the uptake of stress-damaged proteins by dendritic cells via DC-SIGN. Hum. Reprod. 30, 1545-1556 (2015).

14. World Health Organization. Global Strategy for the prevention and control of sexually transmitted infections: 2006-2015 (World Health Organization 2015). Available at www.who.int/hiv/pub/toolkits/stis_strategy\%5B1\% 5Den.pdf.

15. Patel, S. et al. Seminal plasma reduces the effectiveness of topical polyanionic microbicides. J. Infect. Dis. 196, 1394-1402 (2007).

16. Sherman, J.K. \& Morgan, P.N. Effect of human semen on herpes-simplex virus-2. Fertil. Steril. 51, 186-189 (1989).

17. lijima, N. \& Iwasaki, A. T cell memory. A local macrophage chemokine network sustains protective tissue-resident memory CD4 T cells. Science 346, 93-98 (2014).

18. Svensson, A., Nordstrom, I., Sun, J.B. \& Eriksson, K. Protective immunity to genital herpes simplex [correction of simpex] virus type 2 infection is mediated by T-bet. J. Immunol. 174, 6266-6273 (2005).

19. Anderson, R.A. Jr., Oswald, C., Willis, B.R. \& Zaneveld, L.J. Relationship between semen characteristics and fertility in electroejaculated mice. J. Reprod. Fertil. 68, 1-7 (1983). 
20. Anderson, D.J. \& Tarter, T.H. Immunosuppressive effects of mouse seminal plasma components in vivo and in vitro. J. Immunol. 128, 535-539 (1982).

21. Nakanishi, Y., Lu, B., Gerard, C. \& Iwasaki, A. CD8(+) T lymphocyte mobilization to virus-infected tissue requires CD4(+) T-cell help. Nature 462, 510-513 (2009).

22. Schenkel, J.M., Fraser, K.A., Beura, L.K., Pauken, K.E., Vezys, V. \& Masopust, D. T cell memory. Resident memory CD8 T cells trigger protective innate and adaptive immune responses. Science 346, 98-101 (2014).

23. Sung, J.H. et al. Chemokine guidance of central memory $T$ cells is critical for antiviral recall responses in lymph nodes. Cell 150, 1249-1263 (2012).

24. Chang, J.H. et al. Ubc13 maintains the suppressive function of regulatory $T$ cells and prevents their conversion into effector-like Tcells. Nat. Immunol. 13, 481-490 (2012)

25. lijima, N., Linehan, M.M., Saeland, S. \& Iwasaki, A. Vaginal epithelial dendritic cells renew from bone marrow precursors. Proc. Natl Acad. Sci. USA 104, 19061-19066 (2007).

26. Aluvihare, V.R., Kallikourdis, M. \& Betz, A.G. Regulatory T cells mediate maternal tolerance to the fetus. Nat. Immunol. 5, 266-271 (2004).

27. Ernerudh, J., Berg, G. \& Mjosberg, J. Regulatory T helper cells in pregnancy and their roles in systemic versus local immune tolerance. Am. J. Reprod. Immunol. 66(Suppl 1), 31-43 (2011).

28. Shima, T. et al. Regulatory T cells are necessary for implantation and maintenance of early pregnancy but not late pregnancy in allogeneic mice. J. Reprod. Immunol. 85, 121-129 (2010).

29. Munoz-Suano, A., Hamilton, A.B. \& Betz, A.G. Gimme shelter: the immune system during pregnancy. Immunol. Rev. 241, 20-38 (2011).

30. Sakaguchi, S., Yamaguchi, T., Nomura, T. \& Ono, M. Regulatory Tcells and immune tolerance. Cell 133, 775-787 (2008).

31. Lund, J.M., Hsing, L., Pham, T.T. \& Rudensky, A.Y. Coordination of early protective immunity to viral infection by regulatory T cells. Science $\mathbf{3 2 0}$, 1220-1224 (2008).

32. Janssen, E.M., Lemmens, E.E., Wolfe, T., Christen, U., von Herrath, M.G. \& Schoenberger, S.P. CD4 $+T$ cells are required for secondary expansion and memory in CD8 + T lymphocytes. Nature 421, 852856 (2003).

33. Iwasaki, A. Antiviral immune responses in the genital tract: clues for vaccines. Nat. Rev. Immunol. 10, 699-711 (2010).

34. Svensson, A., Tunback, P., Nordstrom, I., Shestakov, A., Padyukov, L. \& Eriksson, K. STAT4 regulates antiviral gamma interferon responses and recurrent disease during herpes simplex virus 2 infection. J. Virol. 86, 9409-9415 (2012).
35. Kohl, S. et al. Limited antibody-dependent cellular cytotoxicity antibody response induced by a herpes simplex virus type 2 subunit vaccine. J. Infect. Dis. 181, 335-339 (2000).

36. Petro, C. et al. Herpes simplex type 2 virus deleted in glycoprotein D protects against vaginal, skin and neural disease. eLife 4, e06054 (2015).

37. Halford, W.P., Geltz, J., Messer, R.J. \& Hasenkrug, K.J. Antibodies are required for complete vaccine-induced protection against herpes simplex virus 2. PLOS ONE 10, e0145228 (2015).

38. Boukhvalova, M. et al. Efficacy of the herpes simplex virus 2 (HSV-2) glycoprotein D/ASO4 vaccine against genital HSV-2 and HSV-1 infection and disease in the cotton rat sigmodon hispidus model. J. Virol. 89, 9825-9840 (2015).

39. Schjenken, J.E., Glynn, D.J., Sharkey, D.J. \& Robertson, S.A. TLR4 signaling is a major mediator of the female tract response to seminal fluid in mice. Biol. Reprod. 93, 68 (2015).

40. Murphy, K.M. \& Reiner, S.L. The lineage decisions of helper T cells. Nat. Rev. Immunol. 2, 933-944 (2002).

41. Williams, M.A. \& Bevan, M.J. Effector and memory CTL differentiation. Annu. Rev. Immunol. 25, 171-192 (2007).

42. Kaushic, C., Ashkar, A.A., Reid, L.A. \& Rosenthal, K.L. Progesterone increases susceptibility and decreases immune responses to genital herpes infection. J. Virol. 77, 4558-4565 (2003).

43. Torres, L., Ortiz, T. \& Tang, Q. Enhancement of herpes simplex virus (HSV) infection by seminal plasma and semen amyloids implicates a new target for the prevention of HSV infection. Viruses 7, 2057-2073 (2015).

44. Zhao, X. et al. Vaginal submucosal dendritic cells, but not Langerhans cells, induce protective Th1 responses to herpes simplex virus-2. J. Exp. Med. 197, 153-162 (2003).

45. Morrison, L.A., Da Costa, X.J. \& Knipe, D.M. Influence of mucosal and parenteral immunization with a replication-defective mutant of HSV-2 on immune responses and protection from genital challenge. Virology 243, 178-187 (1998).

46. lijima, N. et al. Dendritic cells and B cells maximize mucosal Th1 memory response to herpes simplex virus. J. Exp. Med. 205, 3041-3052 (2008).

47. Platt, R.J. et al. CD8 + T lymphocyte epitopes from the herpes simplex virus type 2 ICP27, VP22 and VP13/14 proteins to facilitate vaccine design and characterization. Cells 2, 19-42 (2013).

48. Wang, X. et al. Design and evaluation of a multi-epitope assembly peptide (MEAP) against herpes simplex virus type 2 infection in BALB/c mice. Virol. J. 8, 232 (2011).

49. Carvalho-Gaspar, M., Billing, J.S., Spriewald, B.M. \& Wood, K.J. Chemokine gene expression during allograft rejection: comparison of two quantitative PCR techniques. J. Immunol. Methods 301, 41-52 (2005). 